\title{
DESENVOLVIMENTO DE MUDAS DE CAFEEIRO PRODUZIDAS EM TUBETES, SOB MALHAS TERMO-REFLETORAS E MALHA NEGRA
}

\author{
VINÍCIUS MAIA COSTA
}

\begin{abstract}
Dissertação apresentada à Escola Superior de Agricultura "Luiz de Queiroz", Universidade de São Paulo, para obtenção do título de Mestre em Agronomia, Área de Concentração: Irrigação e Drenagem.
\end{abstract}

\author{
PIR A C I C A B A \\ Estado de São Paulo - Brasil \\ Março - 2004
}




\title{
DESENVOLVIMENTO DE MUDAS DE CAFEEIRO PRODUZIDAS EM TUBETES, SOB MALHAS TERMO-REFLETORAS E MALHA NEGRA
}

\section{VINÍCIUS MAIA COSTA}

Engenheiro Agrônomo

Orientador: Prof. Dr. MARCOS VINÍCIUS FOLEGATTI

\begin{abstract}
Dissertação apresentada à Escola Superior de Agricultura "Luiz de Queiroz", Universidade de São Paulo, para obtenção do título de Mestre em Agronomia, Área de Concentração: Irrigação e Drenagem.
\end{abstract}

\author{
PIR A CICABA \\ Estado de São Paulo - Brasil \\ Março - 2004
}




\title{
Dados Internacionais de Catalogação na Publicação (CIP) DIVSÃO DE BIBLIOTECA E DOCUMENTAÇ̃̃O - ESALQ/USP
}

\author{
Costa, Vinícius Maia \\ Desenvolvimento de mudas de cafeeiro produzidas em tubetes, sob malhas \\ termo-refletoras e malha negra / Vinícius Maia Costa. - - Piracicaba, 2004. \\ 64 p. : il. \\ Dissertação (mestrado) - - Escola Superior de Agricultura Luiz de Queiroz, \\ 2004. \\ Bibliografia. \\ 1. Café 2. Irrigação 3. Mudas 4. Substrato I. Título
}

CDD 633.73

"Permitida a cópia total ou parcial deste documento, desde que citada a fonte - $\mathrm{O}$ autor" 
A meus pais, José Carlos e Marli, e irmãos, Luciano e Danilo, sempre presentes, pelo apoio e amizade. Também à Rafaela e Bárbara, minhas sobrinhas.

OFEREÇO

À Laís, pela presença, apoio e carinho oferecidos. 


\section{AGRADECIMENTOS}

A Deus, pela força em todos os momentos desta jornada;

À Escola Superior de Agricultura "Luiz de Queiroz", por toda sua estrutura que me foi concedida para o desenvolvimento desta pesquisa;

Ao Departamento de Engenharia Rural, pela oportunidade concedida para a realização do mestrado;

Ao Prof. Dr. Marcos Vinícius Folegatti, pela orientação, apoio, incentivo e amizade durante o mestrado;

À Fundação de Amparo à Pesquisa do Estado de São Paulo (FAPESP), pela concessão da bolsa de estudos, assim como o auxílio à pesquisa;

Ao Prof. Dr. Iran José Oliveira da Silva, por conceder a utilização da casa de vegetação onde foi realizada a pesquisa;

Ao Sr. Rubens Chinelato pelas indicações e incentivo profissional;

Aos Professores Dr. Sérgio Nascimento Duarte e Dr. Jarbas Honório de Miranda pelo apoio no período experimental e pelas discussões sobre metodologia;

À Professora Dra. Sônia Maria de Estéfano Piedade pela ajuda na definição do delineamento experimental, e auxílio na parte estatística;

Ao Prof. Dr. Antônio Roberto Pereira por sua contribuição na metodologia de parte desta pesquisa;

Ao Prof. Walter Rodrigues Silva pelas informações sobre as sementes de cafeeiro, juntamente à Helena (Laboratório de Sementes), pelos auxílios prestados; 
Ao Prof. Dr. Casimiro Dias Gadanha Júnior, pela ajuda nos testes dos bicos utilizados na barra de irrigação;

Aos professores do Departamento de Engenharia Rural pelos ensinamentos durante o programa de mestrado;

Ao Msc. Roberto Terumi Atarassi por suas grandes contribuições durante todo o período de mestrado;

Ao Dr. Eliezer Santurbano Gervásio por suas grandes contribuições durante todo o período experimental;

Ao Msc. Cláudio Ricardo da Silva, José Alves Júnior e Msc.Tonny José Araújo da Silva por suas contribuições;

À Msc. Cristiane Guiselini pela colaboração na definição de parte da metodologia utilizada;

Ao Denílson (Garcafé) pelas orientações sobre as mudas de cafeeiro.

À graduanda Paula Bianca Salmazo pelo auxílio, e demais estagiários do GPID;

Aos demais colegas da Pós-graduação em Irrigação e Drenagem;

Aos funcionários do Depto. de Engenharia Rural: Sr. Antônio, Gilmar, Osvaldo, Hélio, César, Sandra, Davilmar, Vanda e Fernanda, por toda colaboração;

Aos funcionários da Biblioteca Central, Eliana e Sílvia em particular, pelo grande auxílio na correção deste material;

Às funcionárias Beatriz, Estela, Márcia Ganzella, Márcia Fecchio e Roseli, da Prefeitura do Campus "Luiz de Queiroz", por todos os auxílios prestados;

Ao Msc. Cícero Leite, pela contribuição com as malhas utilizadas no experimento;

À Magno pela doação dos bicos utilizados na barra de irrigação;

A todos os demais que não foram citados, mas que de forma direta ou indireta contribuíram para que este trabalho se concretizasse. 


\section{SUMÁRIO}

Página

LISTA DE FIGURAS …............................................................. viii

LISTA DE TABELAS …................................................................

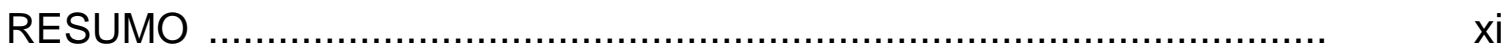

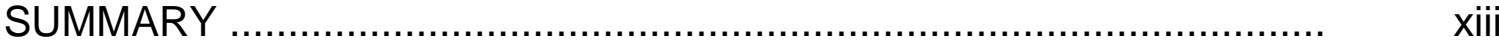

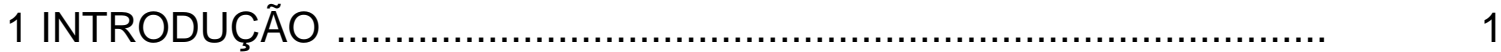

2 REVISÃO DE LITERATURA ........................................................

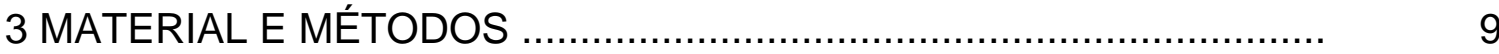

3.1 Local do experimento ..............................................................

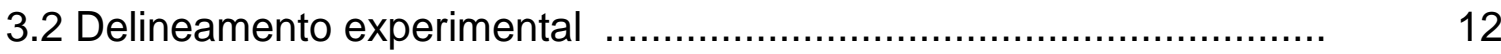

3.3 Instalação das parcelas na área experimental ................................. 15

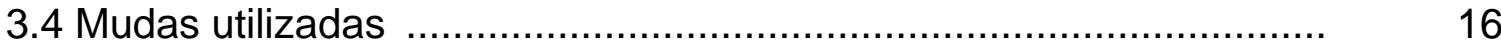

3.4.1 Composição do substrato ……............................................. 16

3.4.2 Fertilizante de liberação controlada .......................................... 17

3.5 Manejo da irrigação ............................................................. 17

3.6 A irrigação e sua eficiência ....................................................... 20

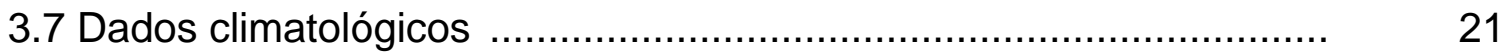

3.8 Aplicações de fertilizantes e defensivos ……................................ 26

3.11 Avaliações …...................................................................... 28

4 RESULTADOS E DISCUSSÃO …................................................. 30

4.1 Variáveis climáticas .............................................................. 30

4.1.1 Temperatura e umidade relativa do ar ....................................... 30 
4.1.2 Radiação global, radiação fotossinteticamente ativa e saldo de radiação ............................................................................. 34

4.2 Desenvolvimento fisiológico ................................................... 40

4.3 Considerações finais ............................................................. 46

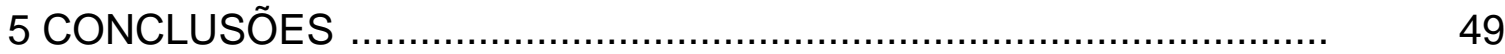

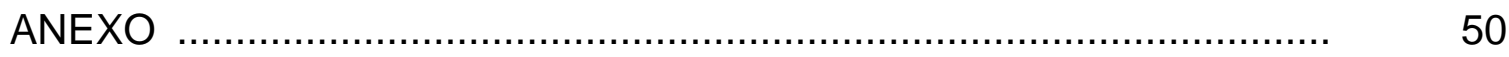

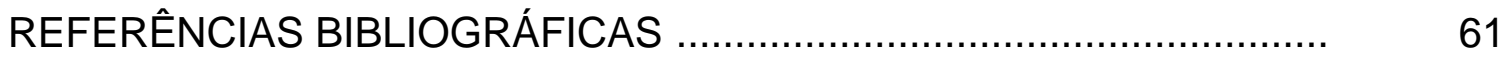




\section{LISTA DE TABELAS}

Página

1 Produtos utilizados durante o período experimental, suas dosagens e respectivas finalidades

2 Médias das variáveis climáticas temperatura e umidade relativa do ar medidas nos horários das 8:00, 12:00 e 16:00 horas

3 Média das variáveis transmissividade das malhas à radiação global (TRG) e fotossinteticamente ativa (TRFA), para os momentos da manhã, intermediário do dia e da tarde, segundo os diferentes tratamentos

4 Média da variável saldo de radiação $\left(\mathrm{W} \mathrm{m}^{-2}\right)$, avaliada para os diferentes tratamentos próxima ao horário do meio dia .....................

5 Análise estatística das variáveis fisiológicas área foliar, diâmetro do caule e altura de mudas de cafeeiro no final do experimento ...........

6 Análise estatística das avaliações das matérias secas da parte aérea, do sistema radicular e total de mudas de cafeeiro no final do

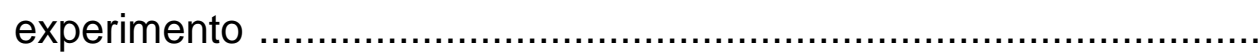




\section{LISTA DE FIGURAS}

Página

1 Detalhes da casa de vegetação utilizada no experimento com suas respectivas dimensões. Vista lateral (a) e vista frontal (b) ................. 10

2 Parte da planta baixa do Departamento de Engenharia Rural (a) e ampliação da casa de vegetação utilizada no experimento, ilustrando a localização das 20 parcelas experimentais (b) .............. 11

3 Croqui da área experimental ...................................................... 13

4 Malha negra 50\% (a); malha termo-refletora $40 \%$ (b), malha termorefletora $50 \%$ (c), malha termo-refletora $60 \%$ (d) e malha termorefletora $70 \%(\mathrm{e})$

5 Montagem dos tratamentos sobre as bancadas, detalhando barra de irrigação localizada no vão entre fechamentos laterais e superiores dos tratamentos

6 Balança de precisão de 0,01g acompanhada do suporte utilizado para pesagem das mudas destinadas à realização do manejo de irrigação

7 Datalogger modelo CR23X instalado no experimento com 2 relês multiplexadores AM416, destinados ao armazenamento dos dados medidos nos psicrômetros

8 Foto ilustrando mochila com datalogger instalado internamente juntamente com a haste de ferro com os sensores de saldo de radiação, de radiação global e de radiação fotossinteticamente ativa (a); detalhe da haste com os sensores (b) 
9 Áreas foliares médias das mudas de cafeeiro medidas em quatro datas ao longo do experimento para os tratamentos avaliados ..........

10 Alturas médias das mudas de cafeeiro medidas em quatro datas ao longo do experimento para os tratamentos avaliados

11 Diâmetros médios das mudas de cafeeiro medidas em quatro datas ao longo do experimento para os tratamentos avaliados

12 Valores médios por tubete das matérias secas da parte aérea (MSPA), do sistema radicular (MSSR) e total (MST) avaliados ao final da experimentação

13 Desidratação seguida de enrijecimento na região do colo em mudas de cafeeiro, em estádio avançado (a), e em detalhe (b) 


\title{
DESENVOLVIMENTO DE MUDAS DE CAFEEIRO PRODUZIDAS EM TUBETES, SOB MALHAS TERMO-REFLETORAS E MALHA NEGRA
}

\author{
Autor: VINÍCIUS MAIA COSTA \\ Orientador: Prof. Dr. MARCOS VINÍCIUS FOLEGATTI
}

\section{RESUMO}

Este experimento avaliou, em casa de vegetação, o desenvolvimento de mudas de cafeeiro produzidas em tubetes, sob o efeito de malhas utilizadas para sombreamento. Os tratamentos utilizados foram a malha negra $50 \%$, conhecida comercialmente como "sombrite" ou "tela preta", considerada padrão para o desenvolvimento destas mudas, e malhas termo-refletoras com quatro diferentes percentagens de atenuação da radiação solar, sendo as malhas $40 \%, 50 \%, 60 \%$ e $70 \%$. O delineamento experimental adotado foi em blocos casualizados contendo os 5 tratamentos, com 4 repetições, totalizando-se assim 20 parcelas. As parcelas foram representadas por 20 bancadas, cada qual contendo fechamento superior com um tipo de malha para sombreamento, e também fechamento nas laterais, atenuando a radiação solar lateral. Cada parcela foi composta por 175 mudas, sendo 161 para bordadura, e 14 para avaliações. As irrigações, realizadas diariamente, foram implementadas com a utilização de uma barra motorizada semi-automatizada que se deslocava 
longitudinalmente na casa de vegetação em ambos os sentidos. A lâmina desejada era ajustada de acordo com a velocidade de deslocamento da barra que era regulada por meio de um inversor de freqüência, responsável por este controle. Para monitorar o microclima, foi instalado interiormente a cada parcela um psicrômetro não ventilado e de tempos em tempos foram realizadas medidas de radiação solar global, fotossinteticamente ativa e o saldo de radiação (SR), estabelecendo-se relações de transmissividade global (TRG) e transmissividade fotossinteticamente ativa (TRFA). As variáveis fisiológicas utilizadas para avaliar o desenvolvimento das mudas foram área foliar, altura das plantas, diâmetro do caule, e, ao final do experimento, foram realizadas análises de matéria seca da parte aérea, do sistema radicular e matéria seca total. A avaliação dos dados psicrométricos mostrou que a temperatura do ar pouco variou nas parcelas, assim como a umidade relativa do ar. Com relação a TRG e TRFA, verificou-se que malhas com menor atenuação da radiação solar apresentaram em geral maior transmissividade, conforme esperado. Para a variável saldo de radiação, a presença de interferências ambientais inviabilizou a maior parte dos dados, verificando-se em apenas parte deles uma tendência de maior SR nas malhas $40 \%$ e $50 \%$. A avaliação das variáveis fisiológicas mostrou que a área foliar não apresentou diferença significativa entre os tratamentos. Já para altura da planta e diâmetro do caule, verificou-se que as mudas produzidas sob as malhas termo-refletoras $40 \%$ e $50 \%$ foram superiores àquelas produzidas sob malha negra 50\% e malhas termo-refletoras $60 \%$ e $70 \%$, respectivamente. Nas avaliações de matéria seca, verificou-se que as mudas produzidas sob as malhas termo-refletoras $40 \%$ e $50 \%$, e malha negra $50 \%$ acumularam mais matéria seca comparativamente àquelas produzidas sob malhas termo-refletoras $60 \%$ e $70 \%$. Assim, nas condições em que desenvolveu-se o experimento, concluiu-se que as malhas termo-refletoras $40 \%$ e $50 \%$ e negra $50 \%$ apresentaram melhores resultados que as malhas termorefletoras $60 \%$ e $70 \%$. 


\title{
DEVELOPMENT OF COFFEE SEEDLINGS PRODUCED IN PLASTIC TUBES, UNDER TERMO-REFLECTIVE AND BLACK SCREENS
}

\author{
Author: VINÍCIUS MAIA COSTA \\ Adviser: Prof. Dr. MARCOS VINÍCIUS FOLEGATTI
}

\section{SUMMARY}

This experiment evaluated, in greenhouse conditions, the development of coffee seedlings produced in plastic tubes, under the effect of screens used for shading. The treatments were black screen 50\%, known commercially as "sombrite" or as "black screen", considered standard for the development of these seedlings, and thermo-reflective screens with four different percentages of attenuation of the solar radiation, being meshes $40 \%, 50 \%, 60 \%$, and $70 \%$. The adopted experimental delineation was randomized blocks with 5 treatments and 4 replicates, making up 20 parcels. The parcels were represented by 20 benches; each one with superior closing system with one type of screen, and also side closing system, attenuating the side solar radiation. Each parcel was composed by 175 seedlings, from which 161 were used as a border, and 14 used for the evaluations. The irrigation, daily carried out, was implemented with the use of a semi-automated motorized bar that dislocated longitudinally along the greenhouse in both directions. The desired water amount was set in 
accordance to the bar displacement speed that was established by means of a frequency inverter, responsible for this control. To monitor the microclimate, one psicrometer was installed inside each parcel and, from time to time, global solar radiation, photosynthetically active radiation, and net radiation (SR) measures were taken, establishing, this way, relations of global transmissivity (TRG) and photosynthetically active transmissivity (TRFA). The physiological variables used to evaluate the development of the seedlings were leaf area, seedlings height, and stalk diameter. Analyses on the dry matter of aerial part and root system and total dry matter were carried out at the end of the experiment. The evaluation of the psicrometers data showed that the temperature of air gently varied in the parcels, as well as the air relative humidity. Relating to TRG and to TRFA, it was verified that screens with less attenuation of the solar radiation presented higher transmissivity in general, as expected. For the variable net radiation, the presence of environment interference made most data impracticable, verifying a partial trend of higher SR in the screens $40 \%$ and $50 \%$. The evaluation of the physiological variables showed that the leaf area did not present significant difference among the treatments. Yet, it was verified that, for seedlings height and stalk diameter, the seedlings produced under thermoreflective screens $40 \%$ and $50 \%$ were superior to those produced under black screen $50 \%$ and thermo-reflective screen $60 \%$ and $70 \%$. It was also verified that, for the evaluations of dry matter, the seedlings produced under thermoreflective screens $40 \%$ and $50 \%$, and black screen $50 \%$ comparatively accumulated more dry matter than those produced under thermo-reflective screens $60 \%$ and $70 \%$. Thus, under the conditions where the experiment was carried out, it can be concluded that the thermo-reflective screens $40 \%$ and $50 \%$ and black screen $50 \%$ presented better results than the thermo-reflective screens $60 \%$ and $70 \%$. 


\section{INTRODUÇÃO}

A cafeicultura brasileira constitui-se numa das mais importantes atividades do setor agroindustrial brasileiro, sendo atualmente a maior em produção no mundo. Isso não garante ao Brasil competitividade no mercado internacional, pois aspectos qualitativos, que visam ao final um café de bebida superior, são mais importantes que a quantidade produzida na concorrência pela comercialização, pois permitem maior agregação de valor ao produto (Hafers \& Saes, 2002).

Tradicionalmente, a produção de mudas de cafeeiro é realizada em viveiros com cerca de $50 \%$ de sombreamento. Pesquisas demonstraram que a atividade da nitrato redutase, enzima essencial para o crescimento vegetal, além de ser influenciada pela temperatura e umidade do ambiente, é maior à sombra que a pleno sol em mudas de Coffea arábica L. com seis meses de idade (Carvalho, 1975; Faleiros et al., 1975). Verificou-se também que as mudas de cafeeiro nesta idade tem um mecanismo de assimilação do nitrogênio diferente daquele das plantas adultas com 36 meses de idade, tendo-se, consequentemente, uma primeira opção bioquímica para explicar o melhor desenvolvimento das mudas à sombra (Cordeiro et al., 1984).

Considerando que as malhas termo-refletoras existentes no mercado, além de produzirem o sombreamento, possuem particulares características que melhoram as condições microclimáticas do ambiente submetido a elas, este trabalho teve como objetivo realizar uma comparação entre quatro malhas termo-refletoras com diferentes percentagens de atenuação da radiação solar, que são respectivamente as malhas 40\%,50\%,60\% e 70\%, com a tradicional 
malha negra 50\%, conhecida comercialmente como "sombrite". O desenvolvimento das mudas foi avaliado tomando como base as medições das seguintes variáveis fisiológicas: altura da planta, diâmetro do caule e área foliar. Ao final do ciclo, todas as mudas de cada parcela foram submetidas a uma análise para determinação da matéria seca do sistema radicular (MSR), da parte aérea (MSPA) e matéria seca total (MST). Além destes dados, foram analisadas variáveis climáticas, sendo elas: temperatura do ar (Tar), umidade relativa do ar (URar), transmissividade à radiação global (TRG), transmissividade à radiação fotossinteticamente ativa (TRFA) e o saldo de radiação (SR).

O experimento foi conduzido na área experimental do Setor de Hidráulica do Departamento de Engenharia Rural da ESALQ/USP a partir de 14/08/2003.

As mudas de cafeeiro utilizadas no experimento eram da cultivar Icatu4045, e foram produzidas em tubetes de $120 \mathrm{~cm}^{3}$, estando no início da pesquisa com apenas o par de folhas cotiledonares formado ("orelha-de-onça"), com aproximadamente 3 meses após semeadura. Elas foram produzidas por semeadura direta nos tubetes em 15/05/2003, utilizando-se $3 / 4$ de substrato comercial mais $1 / 4$ de condicionador de solo em formulação também comercial. A fertilização de base foi realizada utilizando-se o adubo de liberação controlada Basacote Plus $9 \mathrm{M}^{\circledR}$, com formulação 16-08-12 + 2\% de $\mathrm{MgO}+$ micronutrientes, na dosagem de $8,3 \mathrm{~kg} \mathrm{~m}^{-3}$ de substrato. 


\section{REVISÃO DE LITERATURA}

O cafeeiro é uma planta perene pertencente à família Rubiaceae e gênero Coffea. Apenas duas espécies são as responsáveis por cerca de 99\% do café produzido mundialmente, sendo elas Coffea arábica L. e Coffea canephora Pierre, responsáveis, respectivamente, por $74 \%$ e $25 \%$ da produção mundial. Outras espécies responsabilizam-se pelo $1 \%$ restante, sendo estas de menor expressão (Cardoso, 1994).

As primeiras mudas foram introduzidas no Brasil em 1727, e foram cultivadas em Belém do Pará, passando posteriormente ao Maranhão e estados vizinhos, chegando à Bahia em 1770 e ao Rio de Janeiro em 1774. Em 1825, após chegar ao Vale do Paraíba, foi espalhado por São Paulo e Minas Gerais (Matiello, 1991).

A cafeicultura pode ser considerada uma das mais importantes atividades do setor agroindustrial brasileiro e, na atualidade, o Brasil é o maior produtor de café do mundo. Assim, essa é uma cultura que sempre ocupou posição de destaque, não só pela sua importância econômica, mas também social, pois é geradora de grande número de empregos diretos e indiretos, sendo responsável pela fixação de parte da população na zona rural.

Segundo Hafers \& Saes (2002), a concorrência no mercado internacional do café vem aumentando, ocasionada pela entrada de novos países exportadores do produto, como é o caso do Vietnã. Assim, aspectos envolvendo a qualidade do café passaram a ser tão ou mais importantes que a quantidade produzida, não havendo mais espaço para o café brasileiro concorrer por preço; para ser competitivo no mercado globalizado atual, é 
necessário produzir café com qualidade, tendo ao final do processo um café de bebida superior.

Tradicionalmente a produção de mudas de cafeeiro é feita sem agregação de tecnologia. Segundo Guimarães et al. (1989), mudas de cafeeiro são geralmente produzidas em saquinhos plásticos de polietileno, em solo de sub-superfície, fertilizadas com estercos, entre outros compostos orgânicos, e também fertilizantes químicos. Por essas características, a adoção de novas tecnologias para produção de mudas em condições otimizadas, visando a obtenção de plantas mais desenvolvidas e em melhores condições para serem transplantadas ao campo, torna-se indispensável. Algumas técnicas já são largamente utilizadas na produção de mudas de diversas culturas, como a produção de mudas em tubetes, o uso de substratos industrializados (que são livres de patógenos e outros organismos indesejáveis), a fertilização com produtos mais adequados e a irrigação (Melo, 1999).

A produção de mudas sadias e bem desenvolvidas é, portanto, um fator básico, de extrema importância para a formação de novas lavouras cafeeiras. Essas mudas proporcionarão desenvolvimento mais uniforme à lavoura, com maior qualidade e melhores rendimentos por área. Assim, o viveiro, que é o local destinado à germinação das sementes e ao desenvolvimento das mudas, deve ter boa insolação (Guimarães et al., 1989). Esse é um fator essencial, e usualmente a produção de mudas de cafeeiro é realizada recebendo cerca de $50 \%$ da insolação total, pois quando novas, as mudas desenvolvem-se melhor em ambiente de meia-sombra (Matiello, 1991).

Em viveiros de mudas para cafeeiros há formas de se promover sombra que não agregam tecnologia alguma. Guimarães et al. (1989) e Gonçalves \& Tomaziello (s.d.) relataram sobre o uso de bambus, folhas de indaiá, capim colonião, sapé, entre outros. Entretanto, a utilização de malhas negras para sombreamento, que são malhas geralmente confeccionadas em polietileno, já é feita em alguns viveiros, pois conferem sombreamento mais uniforme. As malhas utilizadas são as que proporcionam $40 \%$ a $50 \%$ de sombra (Gonçalves 
\& Thomaziello, s. d.; Guimarães et al., 1989; Instituto Campineiro de Ensino Agrícola, 1973; Matiello, 1991; Moraes, 1970; Thomaziello, 1996) e eventualmente, em condições especiais e altas temperaturas, a proporção poderá ser de $60 \%$ de sombra e $40 \%$ de sol (Gonçalves \& Thomaziello, s.d.).

Alguns estudos voltados para a produção de mudas de cafeiro demonstraram que a atividade da nitrato redutase, enzima essencial para o crescimento vegetal, foi maior à sombra que a pleno sol. Harper \& Paulsen ${ }^{1}$, citados Faleiros et al. (1975), afirmaram que a nitrato redutase é induzível pela luz. No entanto, Cordeiro et al. (1984), estudando a atividade desta enzima em plantas jovens e adultas de Coffea arábica L., em condições de luz e na obscuridade, verificaram que as mudas possuem um mecanismo de assimilação do nitrogênio diferente daquele das plantas adultas. Os autores constataram que a luz não estimulou a atividade desta enzima em mudas de cafeeiro com 6 meses de idade, observando maiores atividades após períodos de escuro. Porém, em plantas adultas com 36 meses de idade, foi verificada a mesma atividade da enzima, tanto à luz, como no escuro. Verificou-se também que, contrariamente ao ocorrido em mudas de cafeeiro, em plantas de soja a atividade da nitrato redutase foi estimulada pela luz.

Carvalho (1975) e Faleiros et al. (1975) também realizaram estudos para avaliar a atividade da nitrato redutase em mudas de C. arabica L. com 6 meses de idade, cultivadas à meia sombra e a pleno sol, com fertilizações nitrogenadas nas formas nítrica e amoniacal. Estes pesquisadores verificaram que, independentemente da forma de disponibilização do fertilizante nitrogenado, as plantas cultivadas à meia sombra desenvolveram-se mais, apresentando melhor aparência, maior área foliar, altura e número de folhas, ocorrendo o inverso nas mudas cultivadas a pleno sol, que ficaram frágeis e com folhas verde-amareladas. Quanto à atividade da nitrato redutase, verificaram maior atividade à meia sombra e menor a pleno sol, para todos os

${ }^{1}$ HARPER, J.E.; PAULSEN, G.M. Influence of intensity, quality and duration of light on nitrogen reduction and assimilation in wheat. Crop Science, v.8, p.537-538, 1968. 
casos analisados, concluindo que a luz plena não é pré-requisito para indução desta enzima para mudas de cafeeiro. Tem-se, consequentemente, uma primeira opção bioquímica para explicar o melhor desenvolvimento das mudas à sombra (Rena \& Maestri, 1987).

Além da luz e da forma de disponibilização dos nutrientes nitrogenados, outras variáveis ambientais, como a temperatura e a umidade, influenciam diretamente na atividade da nitrato redutase (Carvalho, 1975).

Atualmente existem no mercado malhas termo-refletoras que são amplamente utilizadas na agricultura, tanto em campo aberto como em viveiros e telados, e em casas de vegetação. Estas malhas, além de promoverem o sombreamento, possuem algumas características, descritas pela Polysack Plastic Industries (s.d.)(a,b), que as diferem das malhas negras de sombreamento, que são: malhas metalizadas por alumínio em ambas as faces, que promovem devido à metalização, conservação de energia no ambiente, reflexão de parte da energia solar, menores temperaturas no verão e maiores temperaturas no inverno, além de propiciar proteção contra geadas. Os fios das malhas são retorcidos, promovendo a difusão da luz, aumentando a eficiência da fotossíntese.

Hanan (1998) citou que algumas malhas termo-refletoras tem capacidade de conservar energia no ambiente. Segundo Nijskens et al. ${ }^{2}$, citados por Hanan (1998), as malhas termo-refletoras promovem sombreamento, porém, o principal objetivo delas durante o dia é evitar o incremento de temperatura não aceitável, resultante da alta radiação solar.

Silva et al. (1991) realizaram estudo visando avaliar o nível de radiação térmica em ambiente protegido com e sem a utilização de malhas termorefletoras, e concluíram que o uso de malhas termo-refletoras com fios retorcidos aumenta significativamente a quantidade de luz difusa.

2 NIJSKENS, J. et al. Radiation transfer through covering materials, solar in thermal screens of greenhouses. Agricultural and Forest Meteorology, v.35, p.229-242, 1985. 
Valera et al. (2001) verificaram que as malhas termo-refletoras provocam um aumento da temperatura mínima noturna da casa de vegetação, da cultura e do solo, devido à menor perda de radiação de ondas longas, por ser noite e por se ter menor renovação de ar. Os autores afirmaram ainda que tais malhas contribuem para a diminuição da transpiração da cultura à noite, tendo como conseqüência a redução do calor consumido por evapotranspiração.

Medina et al. (2001) realizaram um estudo visando avaliar respostas sazonais da fotossíntese em mudas de laranjeiras da variedade Natal, comparando mudas crescidas em ambiente protegido, sob malha termorefletora 50\%, e mudas crescidas em ambiente protegido sem presença da malha, durante um ano numa propriedade em Holambra - SP. Os autores constataram que, durante as horas do dia com altas temperaturas e alto déficit de pressão de vapor, o tratamento com a malha termo-refletora levou a um ganho de cerca de $30 \%$ em fotossíntese líquida. No ambiente com a malha termo-refletora ocorreram menores temperaturas do ar e das folhas, além de menor déficit de pressão de vapor, independentemente da época do ano. Porém, para a variedade de mudas cítricas estudada, há necessidade de se realizar um manejo de abertura e fechamento da malha durante o dia, de acordo com a radiação global, a temperatura e o déficit de pressão de vapor no ambiente.

Devido ao exposto, poder-se-ia supor que num sistema de produção de mudas de cafeeiro, onde é indispensável o sombreamento devido à atividade da enzima nitrato redutase ser maior em ambiente sombreado, as malhas termo-refletoras promoveriam o sombreamento, como também interfeririam positivamente no microclima do ambiente ao qual as mudas estariam submetidas (pois o ambiente também influencia na atividade da nitrato redutase), garantindo melhor desenvolvimento das mudas. Diante desta situação complexa, onde ocorreriam diversas modificações no ambiente (sombreamento, temperatura do ar, umidade relativa do ar, radiação global e líquida), torna-se interessante determinar por meio da experimentação qual 
seria o material termo-refletor que promoveria os melhores resultados no desenvolvimento das mudas de cafeeiro. 


\section{MATERIAL E MÉTODOS}

\subsection{Local do experimento}

O experimento foi instalado na área experimental do Setor de Hidráulica do Departamento de Engenharia Rural da Escola Superior de Agricultura "Luiz de Queiroz", DER/ESALQ - USP, no município de Piracicaba, Estado de São Paulo, localizado a $22^{\circ} 42^{\prime} 30^{\prime \prime}$ - latitude sul e $47^{\circ} 30^{\prime}$ '00"- longitude oeste de Greenwich, a $546 \mathrm{~m}$ de altitude. O clima do local, segundo a classificação climática de Köppen, é do tipo Cwa, ou seja, sub-tropical úmido, com estiagem no inverno e temperatura média no mês mais frio inferior a $18^{\circ} \mathrm{C}$ e no mês mais quente, superior a $22^{\circ} \mathrm{C}$.

Para sua condução, foi utilizada uma casa de vegetação, instalada no sentido leste-oeste, com dimensões 6,40 m x 17,50 m (largura $\times$ comprimento), totalizando uma área de $112,00 \mathrm{~m}^{2}$, tendo medida de pé-direito $3,00 \mathrm{~m}$. A estrutura, totalmente metálica e composta por materiais galvanizados a fogo, recebeu fechamentos no teto e nas quatro laterais em plástico polietileno de 150 micra transparente, os quais foram substituídos anteriormente ao início do experimento. As laterais, no sentido do comprimento da casa de vegetação, possuíam cortinas plásticas escamoteáveis até a altura do pé-direito, possibilitando sua abertura e fechamento de forma manual.

Nas laterais e teto da casa de vegetação não existiram durante o período experimental fechamentos com quaisquer tipos de malhas para atenuação da radiação solar, pois cada uma das 20 parcelas recebeu, a depender do tratamento, fechamento individualizado com a respectiva malha (termo-refletora 
ou negra), tanto na parte superior como em suas quatro laterais. Assim, com as laterais e teto da casa de vegetação expostos somente à influência do plástico polietileno, evitou-se ao máximo interferências na qualidade e intensidade de radiação que incidiu nas parcelas, com estas ficando expostas somente ao bloqueio da respectiva malha utilizada, além da interferência entre parcelas. A Figura 1 ilustra alguns detalhes da casa de vegetação utilizada no experimento.

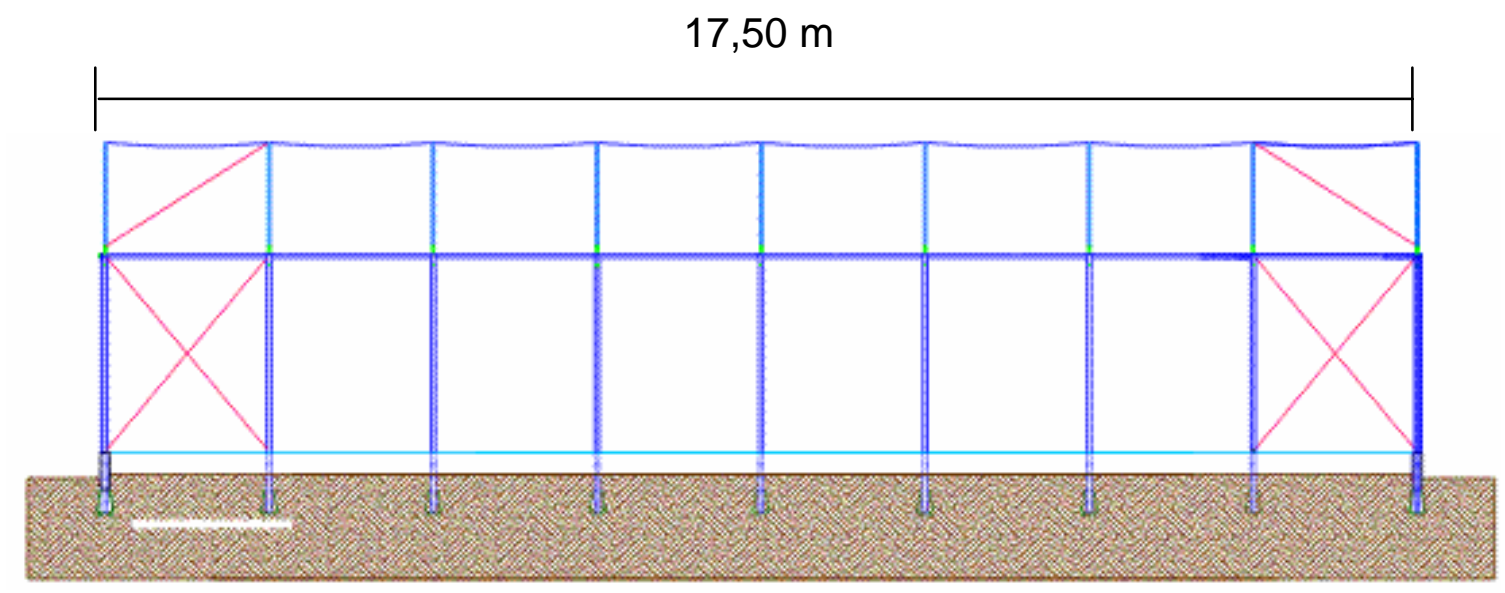

(a)

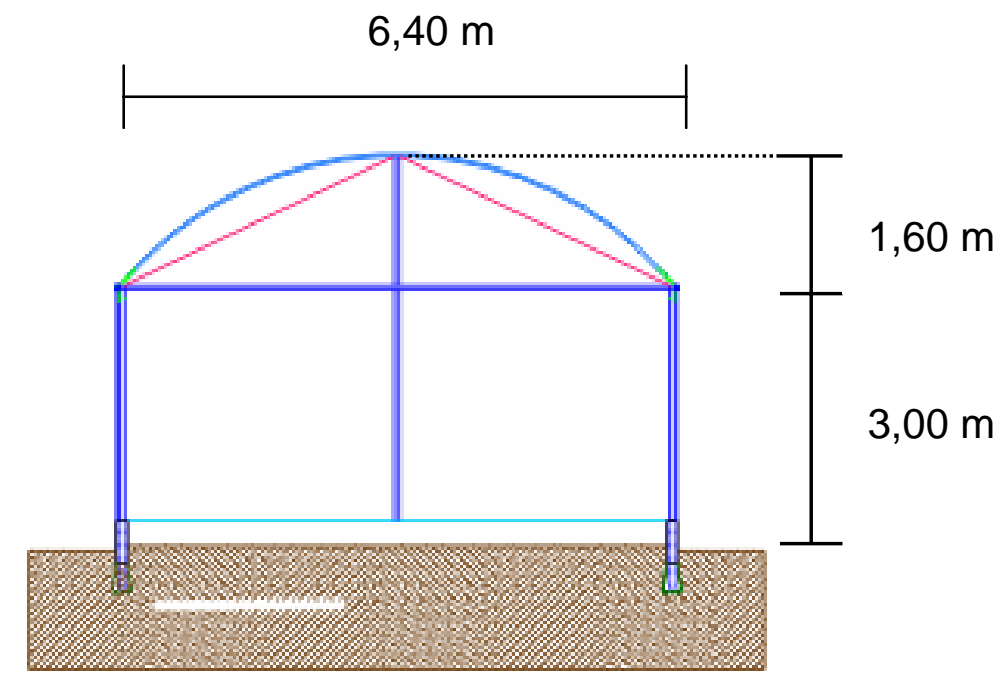

(b)

Figura 1 - Detalhes da casa de vegetação utilizada no experimento com suas respectivas dimensões. Vista lateral (a) e vista frontal (b) 
No sentido longitudinal, internamente ao ambiente, à altura de 2,00 m, foram soldados dois trilhos, um em cada lateral, utilizados como guia e sustentação de uma barra de irrigação semi-automatizada. O espaçamento entre trilhos é de 6,30 m e constitui-se na largura da casa de vegetação, e correspondendo aos dois únicos pontos de apoio deste sistema de irrigação.

O experimento foi conduzido em casa de vegetação para evitar a influência da chuva, porém de forma semelhante às condições de um viveiro de produção de mudas de cafeeiro. A Figura 2 ilustra uma planta baixa de parte do Departamento de Engenharia Rural e uma ampliação esquemática da casa de vegetação utilizada, ambas com seu real posicionamento em relação ao norte geográfico.

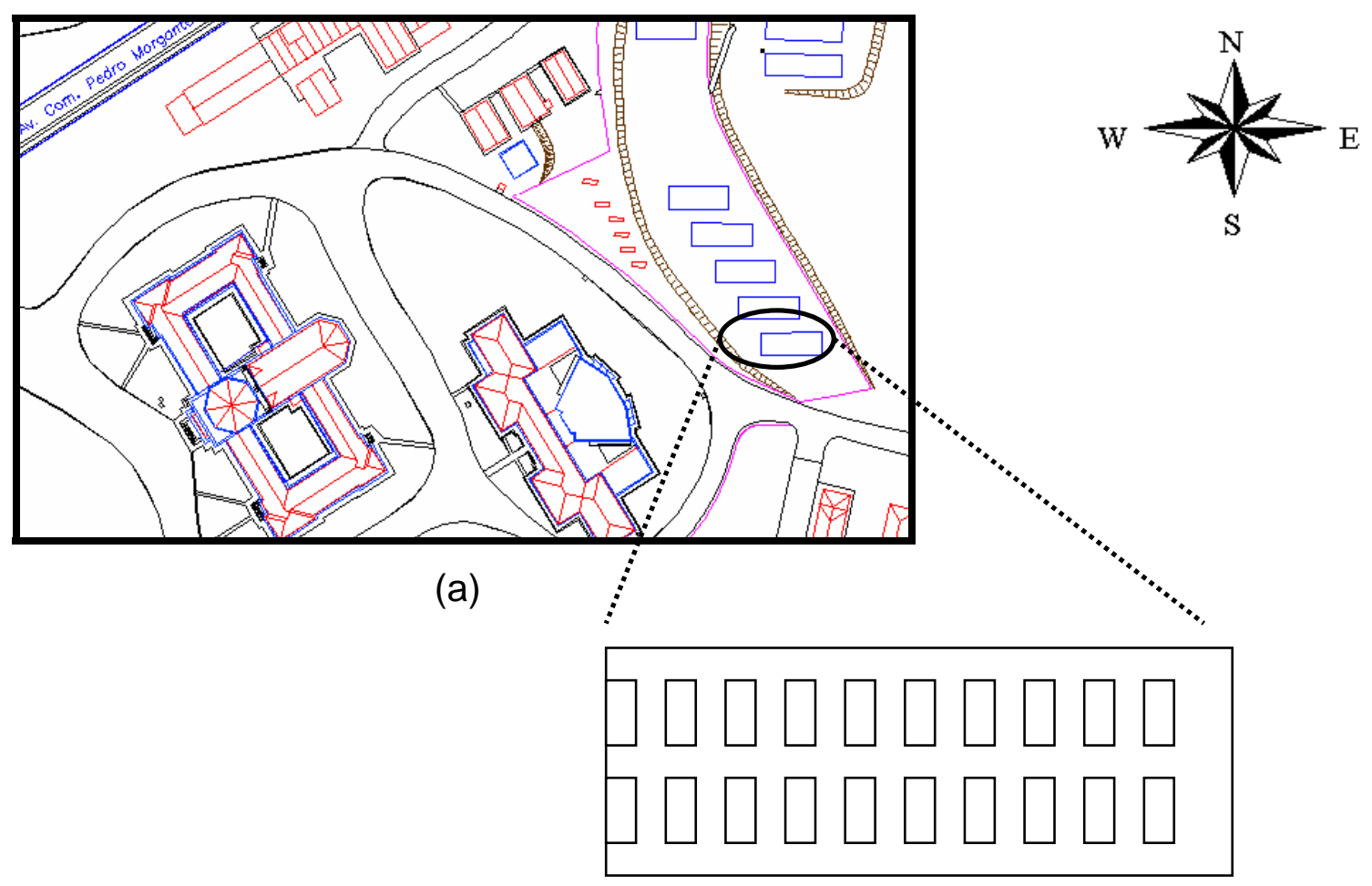

(b)

Figura 2 - Parte da planta baixa do Departamento de Engenharia Rural (a) e ampliação da casa de vegetação utilizada no experimento, ilustrando a localização das 20 parcelas experimentais (b) 


\subsection{Delineamento experimental}

O delineamento experimental utilizado foi o de blocos casualizados, formados por cinco tratamentos, e quatro repetições, totalizando vinte parcelas. Para as avaliações das variáveis fisiológicas foi adotado um esquema de avaliações no tempo, tendo-se diferentes épocas de avaliação, ou seja, com coleta destas variáveis com a freqüência de 25 dias. O início do experimento foi caracterizado quando as mudas estavam no estádio de desenvolvimento denominado "orelha de onça", que é o par de folhas cotiledonares.

As parcelas foram constituídas por 20 bancadas confeccionadas em ferro, com dimensões 1,20 m de largura por 1,40 m de comprimento e 0,90 m de altura em relação ao solo, tendo sido dispostas em duas fileiras paralelas no sentido longitudinal da casa de vegetação. Em cada fileira o espaçamento entre bancadas foi de 0,55 m e entre fileiras de 1,40 m. Cada parcela foi composta por 175 mudas dispostas sobre uma tela metálica com malha $4 \mathrm{~cm} \times 4 \mathrm{~cm}$, suficiente para suprir o apoio necessário a elas. Esta tela foi fixada através de solda à bancada.

Destas 175 mudas, 14 foram utilizadas para realizar as medidas das variáveis fisiológicas, tendo-se, portanto, 161 mudas de bordadura, as quais foram distribuídas uniformemente nas laterais do espaço amostral. O croqui da área experimental esta ilustrado pela Figura 3. 


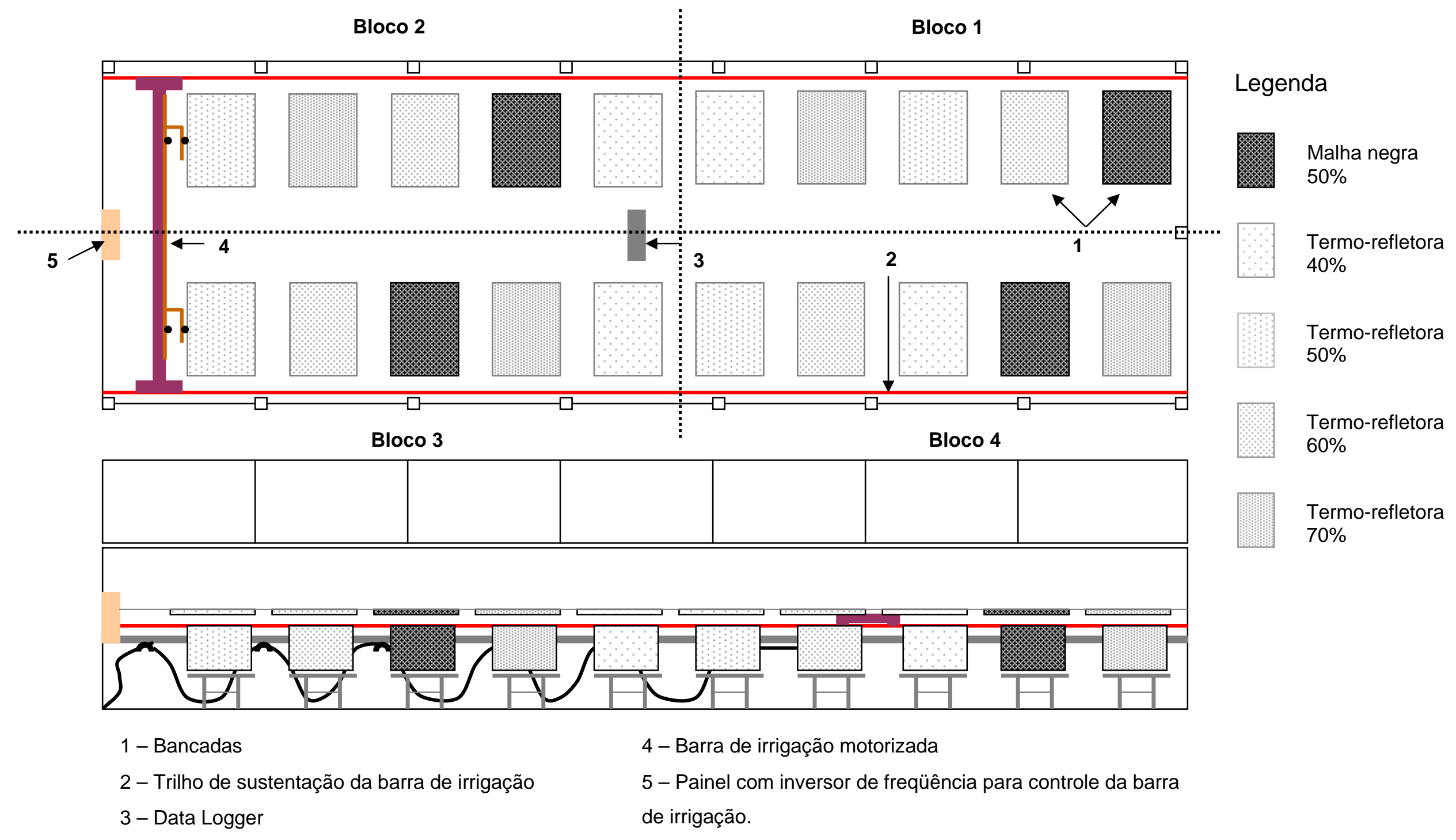

Figura 3 - Croqui da área experimental 
Os tratamentos foram constituídos por quatro tipos de malhas termorefletoras e uma malha negra utilizada como padrão. As malhas termorefletoras possuíam respectivamente $40 \%, 50 \%, 60 \%$ e $70 \%$ de atenuação da radiação solar, e o material padrão, utilizado como controle, foi a malha negra com $50 \%$ de atenuação da radiação solar. Detalhes das malhas estão ilustrados na Figura 4.

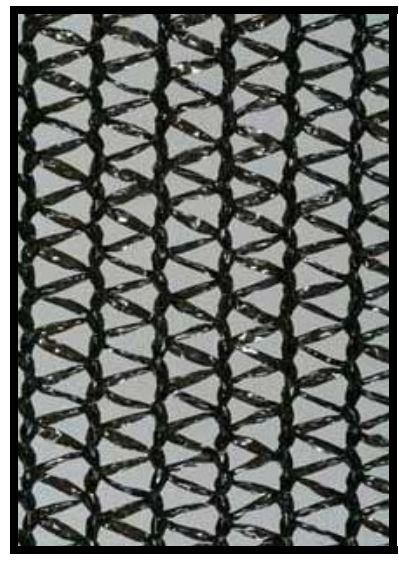

(a)

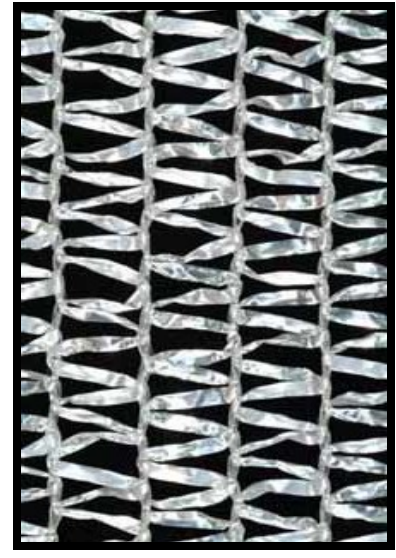

(b)

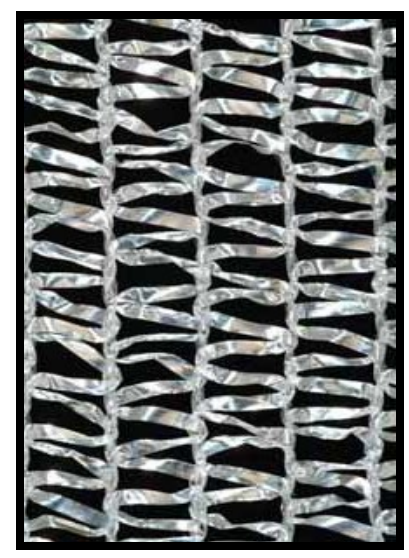

(c)

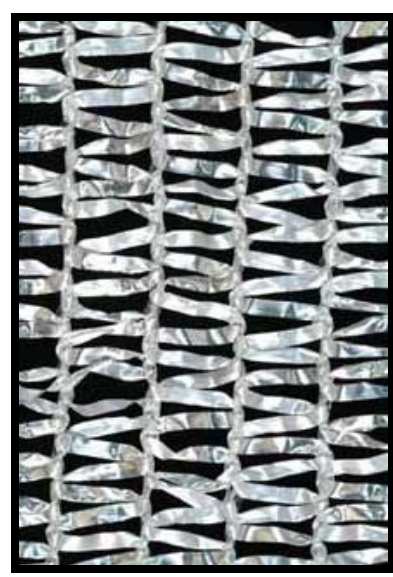

(d)

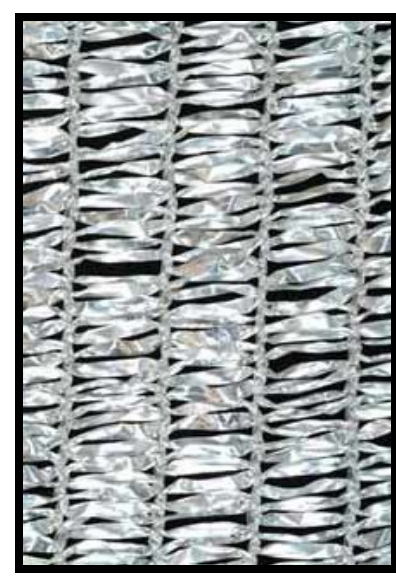

(e)

Figura 4 - Malha negra 50\% (a); malha termo-refletora 40\% (b), malha termorefletora $50 \%$ (c), malha termo-refletora $60 \%$ (d) e malha termorefletora $70 \%(\mathrm{e})$ 


\subsection{Instalação das parcelas na área experimental}

De maneira aleatória, foi realizada a distribuição dos blocos e tratamentos no interior da casa de vegetação. Em cada parcela, uma estrutura confeccionada em ferro tipo vergalhão foi alocada sobre a bancada, servindo como estrutura para sustentação da respectiva malha, isolando-se lateralmente cada tratamento. Para o fechamento superior em cada tratamento, foram utilizados arames galvanizados dispostos no sentido longitudinal da casa de vegetação, sustentados pelas estruturas das partes frontais desta. Este aparato serviu de apoio para todas as malhas superiores, possibilitando que estas permanecessem esticadas. Desta forma, formou-se um vão de cerca de 0,25 m entre o fechamento lateral e o superior, através do qual a barra de irrigação pôde transitar livremente, sem o comprometimento de seu desempenho (Figura 5).

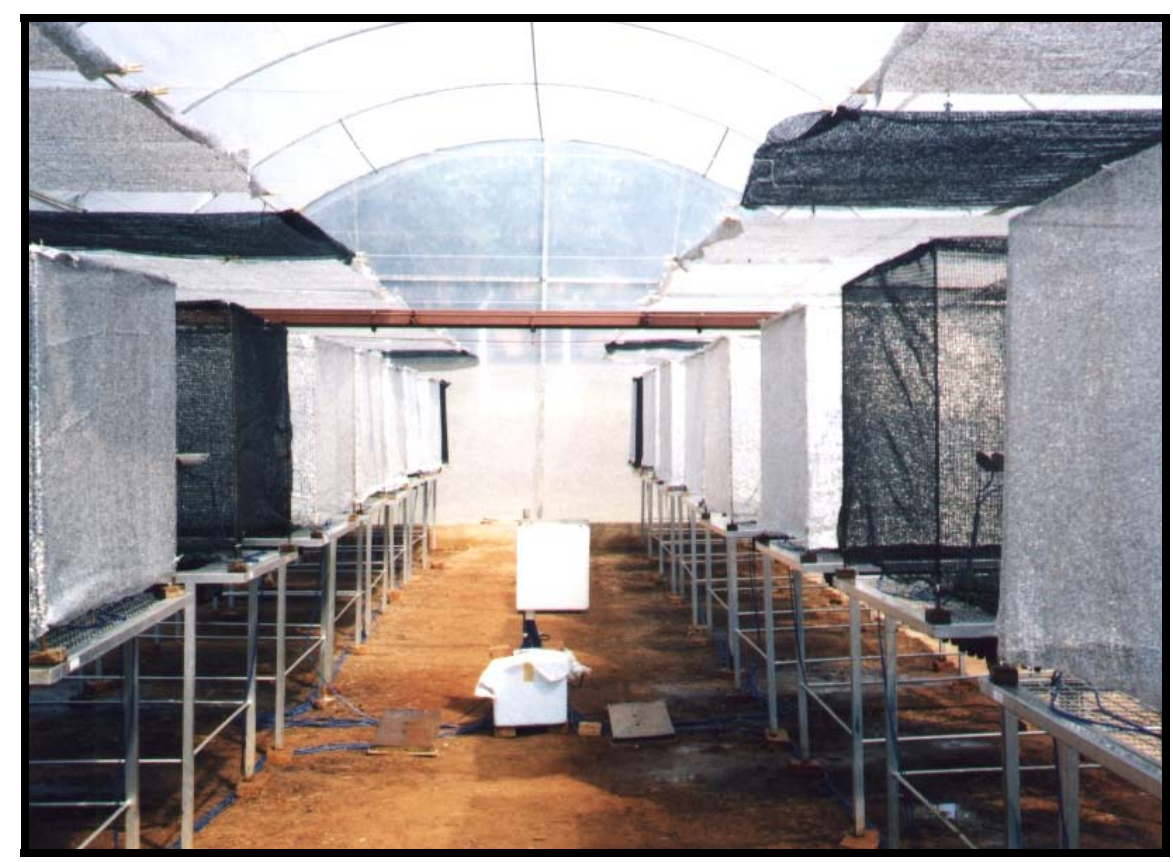

Figura 5 - Montagem dos tratamentos sobre as bancadas, detalhando barra de irrigação localizada no vão entre fechamentos laterais e superiores dos tratamentos 


\subsection{Mudas utilizadas}

As mudas utilizadas no experimento foram obtidas por meio de sementes da cultivar Icatu-4045, e foram adquiridas junto a Garcafé - Cooperativa dos Cafeicultores da Região de Garça, no estádio de desenvolvimento "orelha de onça", ou seja, com o par de folhas cotiledonares formado, com idade de 91 dias após a semeadura. Estas foram produzidas por semeadura direta, realizada nos tubetes de $120 \mathrm{~cm}^{3}$, no dia 15/05/2003. No dia 14/08/2003, quando as mudas foram trazidas à área experimental, deu-se início ao experimento.

Como substrato, utilizou-se uma mistura composta por 2 produtos comerciais orgânicos. A fertilização de base foi realizada utilizando-se o adubo de liberação controlada Basacote Plus $9 \mathrm{M}^{\circledR}$, da Compo. A liberação deste adubo ocorre gradualmente, proporcionalmente à variação da temperatura do meio e do substrato. O enchimento dos tubetes foi efetuado com auxílio de uma máquina elétrica para evitar grandes disparidades na densidade de substrato entre os tubetes utilizados.

Desta forma, ao entrarem na área experimental, as mudas foram imediatamente alocadas, distribuindo-se 175 mudas em igual disposição em cada uma das 20 parcelas, perfazendo-se ao todo 3500 mudas.

\subsubsection{Composição do substrato}

O substrato utilizado na produção das mudas foi uma associação de dois produtos orgânicos comerciais. Um dos componentes foi $3 / 4$ de substrato Plantmax-Café ${ }^{\circledR}$, um produto à base de vermiculita e perlita expandidas, cascas de pinus e turfa processadas que tem, segundo o fabricante, capacidade máxima de retenção de água ao redor de $150 \%$, umidade natural ao redor de 50 a $60 \%$ (base peso), condutividade elétrica entre 0,5 e $1,3 \mathrm{ds} \mathrm{m}^{-1}$ (1:2, base volume) e $\mathrm{pH}$ variando entre 5,5 e 6,2 . Os $1 / 4$ restantes foram compostos pelo 
produto Solomax ${ }^{\circledR}$, um condicionador de solos rico em matéria orgânica, estabilizado de forma a não ocorrer fermentações secundárias. O condicionador de solo tem como características de capacidade máxima de retenção de umidade, umidade natural (base peso), condutividade elétrica (1:2, base volume) e $\mathrm{pH}$, similares àquelas encontradas no Plantmax-Café ${ }^{\circledR}$.

Para o preparo da mistura de substratos, foi seguido o critério do fabricante, que preconiza a adição de 5 litros de água para cada 25 litros de substrato.

\subsubsection{Fertilizante de liberação controlada}

A fertilização de base foi realizada utilizando-se o adubo de liberação controlada Basacote Plus $9 \mathrm{M}^{\circledR}$ na dosagem de $8,3 \mathrm{~kg} \mathrm{~m}^{-3}$ de substrato. Este adubo foi misturado ao substrato imediatamente antes do enchimento em máquina elétrica.

Segundo o fabricante, este fertilizante é próprio para a utilização em substratos e tem formulação $16-08-12+2 \%$ de $\mathrm{MgO}+$ micronutrientes. É recoberto por uma película de Poligen ${ }^{\circledR}$, que proporciona a liberação lenta dos nutrientes por cerca de 9 meses, tempo este que varia com a temperatura do substrato.

\subsection{Manejo da irrigação}

A irrigação foi realizada com utilização de um equipamento semiautomatizado, desenvolvido especificamente para este experimento. Este equipamento constitui-se de uma barra transversal motorizada, que se desloca no sentido longitudinal da casa de vegetação, equipado com emissores pulverizadores de jato plano tipo "leque" (Anexo).

O manejo da irrigação foi caracterizado pela adoção de duas metodologias distintas. A primeira foi adotada segundo recomendação de 
Guimarães et al. (1989). Nesta, no dia inicial do experimento, ou seja, em 14/08/2003, quando as mudas no estádio de desenvolvimento "orelha de onça" foram alocadas nas parcelas, a lâmina de irrigação aplicada foi de 2,5 mm diários, divididos em duas etapas de aplicação, sendo uma no período da manhã e outra no período da tarde. Essa lâmina aplicada estendeu-se até o surgimento do primeiro par de folhas definitivo, caracterizado pelo dia 08/09/2003.

Após esta etapa, a lâmina diária passou a ser de 4,5 mm. Porém, como a aplicação de uma lâmina fixa não levava em consideração a variação da evapotranspiração da cultura, optou-se por uma metodologia mais apurada. Desta maneira, a partir de 25/09/2003 a metodologia de determinação do consumo de água da cultura consistiu na estimativa da evapotranspiração com base em um método gravimétrico, utilizando-se uma balança com precisão de 0,01 g. Neste método, de 7 em 7 dias aproximadamente, uma amostra de 15 mudas, composta por 3 tubetes de cada parcela de um bloco era colocada em um suporte, e posteriormente mergulhado em um recipiente com água até o nível chegar ao segundo terço dos tubetes. Esta amostra era deixada por 1 hora para saturar e mais 1 hora para drenagem. Após este processo de 2 horas, pesava-se o conjunto, considerando-se este peso do conjunto de 15 tubetes mais o suporte como correspondente a uma umidade do substrato equivalente à capacidade de contêiner (ou capacidade de campo). Esta rotina foi repetida com a freqüência de 7 dias para evitar o efeito do desenvolvimento vegetativo decorrente do crescimento das mudas durante este período. Esta atividade foi sempre exercida nas primeiras horas da manhã.

À tarde, neste mesmo dia, este conjunto era novamente pesado. A diferença em peso entre a pesagem da manhã, em capacidade de contêiner, e a pesagem da tarde era considerada como perda d'água por evapotranspiração.

Para o cálculo da lâmina de irrigação foi utilizada uma unidade de área de $0,03054 \mathrm{~m}^{2}$, área esta que representa 2 vezes a área de coleta de 15 
tubetes. Esta área foi utilizada como base de cálculo para as lâminas de irrigação no intuito de amenizar alguns problemas encontrados em experimentos similares, conforme descrito por Gervásio (2003), no qual em alguns casos encontraram-se lâminas de irrigação com eficiência superior a $100 \%$. O autor atribuiu esta ocorrência à arquitetura das folhas da planta, a qual funcionava como um coletor da água que era aspergida no momento da irrigação, convergindo-a para o interior do tubete. Também pôde-se observar que à medida que as plantas desenvolviam-se, as folhas ultrapassavam a área da boca do tubete, convergindo para dentro do recipiente aquela água que cairia fora dele.

A fim de se evitar lâminas de irrigação maiores que aquelas desejadas, convencionou-se que esta unidade de área de 0,03054 $\mathrm{m}^{2}$ seria correspondente à área dos 15 tubetes. Este valor foi tomado como base para estimar a evapotranspiração durante todo o período no qual esta segunda metodologia de irrigação foi adotada. A Figura 6 ilustra o material utilizado na realização das pesagens em balança de precisão.

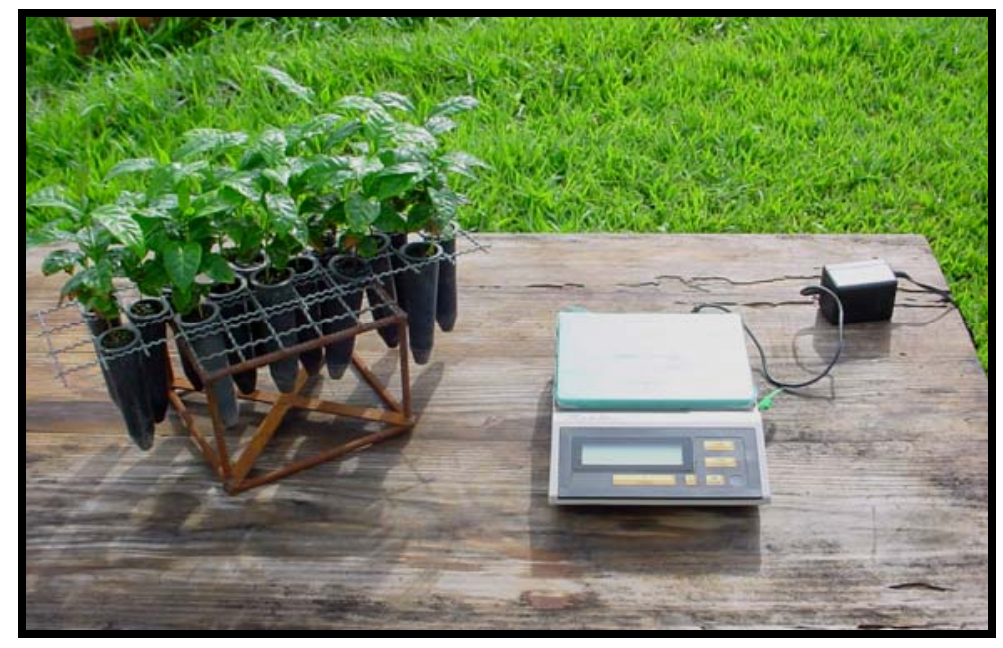

Figura 6 - Balança de precisão de 0,01g acompanhada do suporte utilizado para pesagem das mudas destinadas à realização do manejo de irrigação 


\subsection{A Irrigação e sua eficiência}

De acordo com a segunda metodologia de determinação do consumo de água utilizada no experimento, na qual um processo gravimétrico foi utilizado como base de cálculo para estimar o volume evapotranspirado pelas mudas durante um certo período de tempo, houve a necessidade de se adotar um método para verificação da real lâmina armazenada nos tubetes após a irrigação.

Após a determinação da capacidade de contêiner dos 15 tubetes utilizados como padrão em uma dada semana (pois a freqüência desta determinação foi semanal), para as irrigações sub-seqüentes, a determinação das lâminas foi realizada tomando como base este valor semanal para capacidade de contêiner. Assim, a primeira irrigação realizada após a determinação da capacidade de contêiner era cumprida considerando-se uma eficiência deste sistema como 100\%. Vale ressaltar que para todas as irrigações efetuadas durante o experimento, não houve interferências relacionadas a vazamentos na parte hidráulica do sistema, a ventos ou outros fatores externos.

Assim, após a aplicação da lâmina calculada, aquele mesmo conjunto de tubetes era novamente colocado na bandeja para pesagem e as folhas das plântulas eram secadas uma a uma com um papel absorvente, objetivando a remoção do excesso de água acumulado nas folhas e que não escoou para o tubete, não compondo, portanto, a fração de água armazenada. Após esta tarefa, a amostra era novamente pesada na balança de precisão de 0,01 g. A diferença encontrada entre o peso conhecido previamente como capacidade de contêiner e este peso final foi atribuído à água que realmente ficou armazenada no sistema. Com isso, calculava-se a eficiência da irrigação conforme a Eq. 1. 
$E f=\left(\frac{\text { LAMarm }}{\text { LAMapl }}\right) 100$

(1)

em que:

Ef - eficiência da irrigação, \%;

LAM arm - lâmina de irrigação armazenada nos tubetes, mm;

LAM apl - lâmina de irrigação aplicada, mm.

Esta eficiência calculada servia como correção a ser utilizada em todas as irrigações na semana seqüente. Efetuava-se para uma dada irrigação a pesagem do conjunto e a determinação do peso, e com a diferença entre e o peso na capacidade de contêiner calculado para esta semana e este peso encontrado, calculava-se o volume evapotranspirado. Em seguida determinavase a lâmina e dividia-se a mesma pela eficiência, sendo esta lâmina corrigida aquela utilizada naquele momento para a irrigação, tal como apresentado na Eq 2.

LAMapl $=\frac{\text { LAMevpt }}{\text { Ef }}$

em que:

LAMevpt - lâmina evapotranspirada, mm.

\subsection{Dados climatológicos}

No decorrer do experimento foram realizados alguns monitoramentos de variáveis climáticas, que foram: temperatura, umidade relativa do ar, radiação global, radiação fotossinteticamente ativa e saldo de radiação. Destes, as variáveis coletadas por um período maior foram temperatura e umidade relativa 
do ar, a partir de 20/09/2003. Utilizaram-se 20 psicrômetros não aspirados, com termopares de cobre-constantan para efetuar as medidas de temperatura real do ar, ou seja, temperatura em bulbo seco, e a temperatura com bulbo envolto em uma gaze de algodão umedecida.

Em cada parcela do experimento foi instalado um psicrômetro, todos em mesma posição em cada bancada, visando medir possíveis variações na temperatura e umidade relativa nas parcelas ao longo do dia. Sua instalação foi feita a 0,35 $\mathrm{m}$ da superfície da tela de apoio dos tubetes e a cerca de 1,25 m em relação à superfície do solo. Todos os 20 psicrômetros tiveram dados de temperatura de bulbos seco e úmido coletados de 5 em 5 segundos, dos quais retiravam-se médias horárias e diárias através de um sistema de aquisição de dados (datalogger) utilizado para o recebimento e gravação destes dados. O datalogger utilizado foi o modelo CR23X, da Campbell Scientific ${ }^{\circledR}$, equipado com dois relês multiplexadores modelo AM416, também da Campbell Scientific $^{\circledR}$. Este equipamento instalado no experimento está ilustrado pela Figura 7.

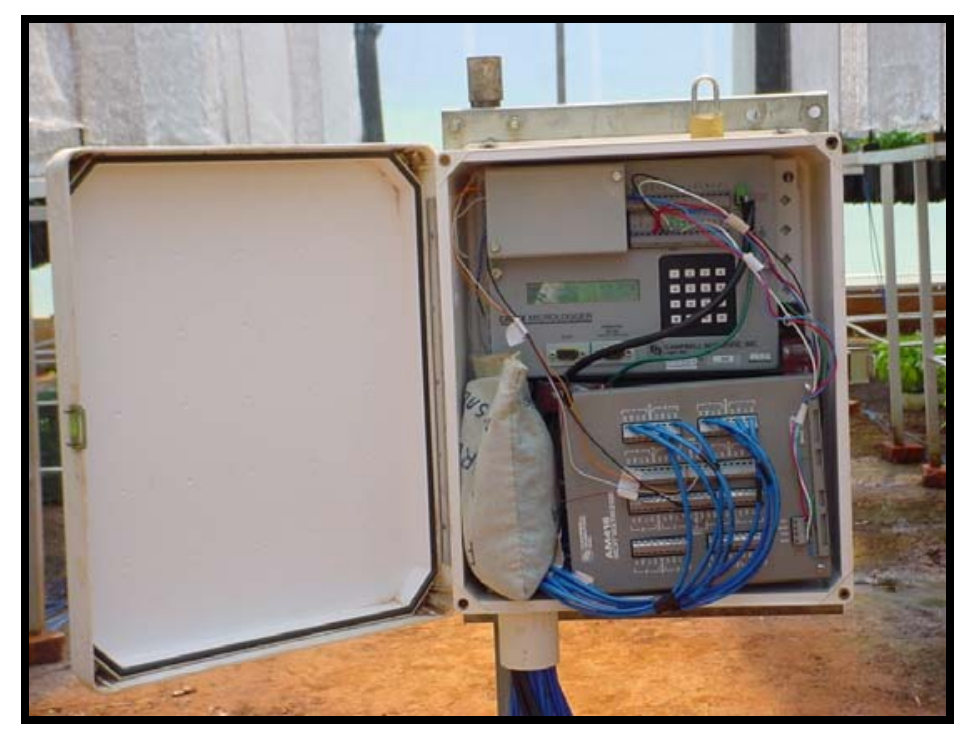


Figura 7 - Datalogger modelo CR23X instalado no experimento, com 2 relês multiplexadores AM416, destinados ao armazenamento dos dados medidos nos psicrômetros

Com as medições de temperatura do ar pôde-se determinar a pressão atual de vapor da atmosfera $\left(e_{a}\right)$ por meio da equação psicrométrica descrita por Pereira et al. (2002), representada pela Eq. 3.

$\mathrm{e}_{\mathrm{a}}=\mathrm{e}_{\mathrm{su}}-\gamma(\mathrm{Ts}-\mathrm{Tu})$

em que:

$\mathrm{e}_{\mathrm{a}}$ - pressão atual de vapor da atmosfera, $\mathrm{kPa}$;

$\mathrm{e}_{\mathrm{su}}$ - pressão de saturação de vapor da atmosfera com base em Tu, $\mathrm{kPa}$;

$\gamma$ - constante psicrométrica, $\mathrm{kPa}^{\circ} \mathrm{C}^{-1}$;

Ts - temperatura do ar em bulbo seco, ${ }^{\circ} \mathrm{C}$;

$\mathrm{Tu}$ - temperatura do ar em bulbo úmido, em ${ }^{\circ} \mathrm{C}$.

Para generalizar a aplicação da equação 3 em qualquer localidade, fazse necessária a correção da constante psicrométrica de acordo com Eq. 4 e Eq. 5.

$\gamma=(\mathrm{CP})$

$P=760\left(1-\frac{0,0065 Z}{288}\right)^{5,2568}$

em que:

C - constante para psicrômetros não ventilados, $0,00080^{\circ} \mathrm{C}^{-1}$;

$\mathrm{P}$ - pressão atmosférica do local, $\mathrm{mmHg}$;

$\mathrm{Z}$ - altitude da localidade, $\mathrm{m}$. 
Fundamentado por estes dados, pôde-se então determinar a umidade relativa do ar, conforme a Eq. 6 descrita por Pereira et al. (2002).

$\mathrm{UR}=\left(\frac{\mathrm{e}_{\mathrm{a}}}{\mathrm{e}_{\mathrm{s}}}\right) 100$

em que:

UR - umidade relativa do ar, \%;

$\mathrm{e}_{\mathrm{s}}$ - pressão de saturação de vapor da atmosfera com base em Ts, $\mathrm{kPa}$.

Foi utilizado para as estimativas de radiação global um piranômetro de silício da Kipp \& Zonen ${ }^{\circledR}$, modelo SP Lite; para as estimativas de saldo de radiação, utilizou-se um saldo radiômetro Kipp \& Zonen ${ }^{\circledR}$, modelo NR Lite; finalmente, para as estimativas da radiação fotossinteticamente ativa, utilizou-se um sensor $\mathrm{Li}^{-\mathrm{COr}^{\circledR}}{ }^{\circledR}$, modelo Quantum. Para armazenar os dados destas estimativas de radiação, os sensores foram conectados a um datalogger modelo CR10X, da Campbell Scientific ${ }^{\circledR}$.

Nas estimativas envolvendo a radiação solar, adotou-se um critério de 3 coletas de dados ao longo do dia, sendo uma no período da manhã, outra próxima das 12:00 horas e finalmente a terceira ao final da tarde, próxima das 17:00 horas. Estas coletas foram efetuadas em cinco dias aleatórios compreendidos entre 14/11/2003 e 15/12/2003. Assim, montou-se em uma mochila, que podia ser carregada nas costas, um suporte interno responsável pela fixação do conjunto datalogger + bateria, e para os sensores, desenvolveuse uma haste em ferro tubular de $12,7 \mathrm{~mm}$, de modo que facilitasse seu manuseio no experimento. A Figura 8 ilustra este conjunto de equipamento. 


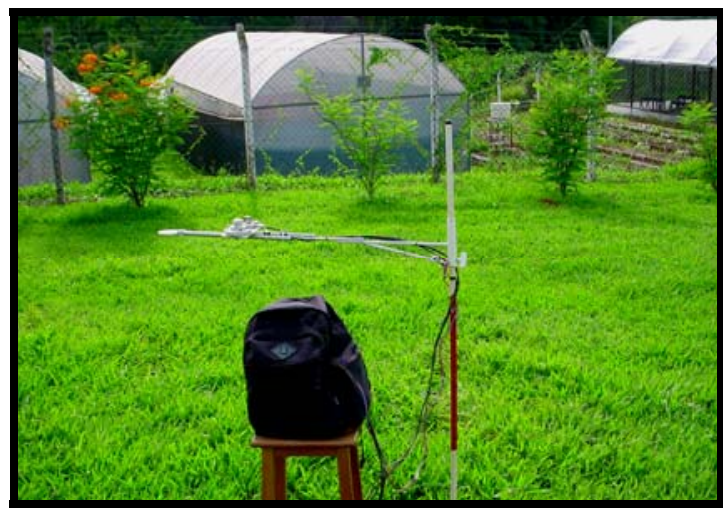

(a)

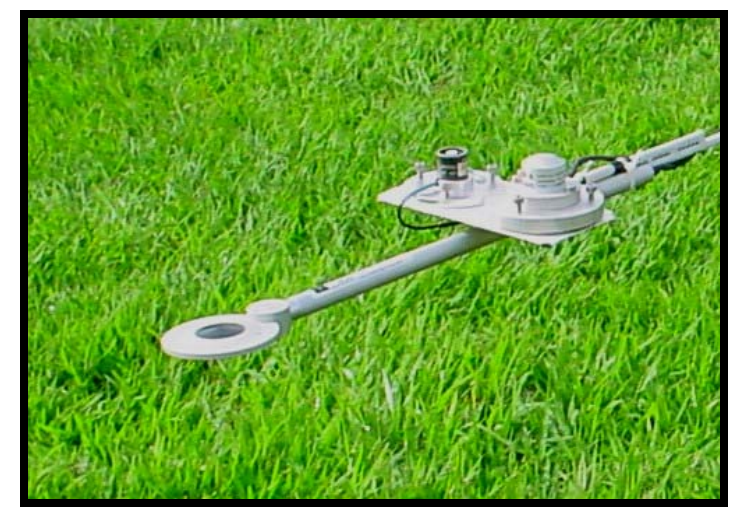

(b)

Figura 8 - Foto ilustrando mochila com datalogger instalado internamente juntamente com a haste de ferro com os sensores de saldo de radiação, de radiação global e de radiação fotossinteticamente ativa (a); detalhe da haste com os sensores (b)

Este conjunto foi construído para possibilitar versatilidade para a movimentação em campo, pois nos dias em que foram coletados os elementos relativos à radiação solar em cada tratamento, dentro da casa de vegetação, por 3 vezes ao dia, este equipamento foi carregado ao campo. O critério adotado para as estimativas de radiação foi estabelecido da seguinte forma: os dados de radiação coletados em todas as 20 parcelas do experimento seguiam sempre a mesma seqüência de parcela para parcela. Desta forma, coletava-se dados no interior do tratamento submetido a algum tipo de malha, e em seguida fora do tratamento, porém próximo deste. Dessa forma, eram então realizadas 20 coletas interiormente aos tratamentos e 20 fora deles, seguindo-se sempre a seqüência "dentro do tratamento" e "fora do tratamento", totalizando 40 dados por coleta, todas no interior da casa de vegetação.

Para possibilitar a escolha dos momentos em que realmente se desejava que o sistema de aquisição de dados gravasse as informações, foi desenvolvido 
um programa por $A$ tarassi ${ }^{1}$, possibilitando que as gravações pudessem ser realizadas mediante o acionamento de um botão. Foi programado um tempo de coleta de 10 segundos, sendo que a confirmação do acionamento do sistema era verificada por meio de uma lâmpada que se acendia assim que o sistema era acionado, apagando-se automaticamente para acusar o desligamento do sistema.

\subsection{Aplicações de fertilizantes e defensivos}

Durante todo o período experimental foram efetuadas algumas aplicações de defensivos e de fertilizantes. Não foi seguido qualquer critério quanto à freqüência das aplicações, tanto para adubação como para a aplicação de defensivos.

As atividades de fertilização foram realizadas de tempos em tempos, aplicando-se o fertilizante foliar Niphokam $108^{\circledR}$, composto por macro e micronutrientes, na dosagem recomendada pelo fabricante. As aplicações com fungicida com princípio ativo Thiophanato Metilico $\left(\right.$ Cercobin $\left.^{\circledR}\right)$ foram preventivas, e foram executadas no período inicial do experimento, não tendo sido posteriormente verificados pontos de infecção com qualquer tipo de fungo. Já as utilizações de inseticida com princípio ativo Clorpirifós (Lorsban $480 \mathrm{BR}^{\circledR}$ ) foram efetuadas de acordo com o surgimento de plântulas com folhas atacadas por larva minadora. Todas as fertilizações utilizando-se o adubo foliar, assim como as aplicações de defensivos, foram feitas com utilização de uma bomba costal com capacidade para 20 litros.

A fertirrigação foi realizada aplicando-se uma solução contendo $40 \mathrm{~g}$ de monoamônifosfato (MAP) purificado, composto por $60,7 \%$ de $\mathrm{P}_{2} \mathrm{O}_{5}$ e $11,8 \%$ de $\mathrm{N}$, mais $50 \mathrm{~g}$ de nitrato de potássio $\left(\mathrm{KNO}_{3}\right)$, contendo $13,51 \%$ de $\mathrm{N}$ e $45,47 \%$ de

${ }^{1}$ ATARASSI, R.T.A (ESALQ. Departamento de Engenharia Rural - Setor de Hidráulica, Piracicaba). Comunicação pessoal, 2003. 
$\mathrm{K}_{2} \mathrm{O}$. Foi preparado um volume de 50 litros, e aplicaram-se 2,5 litros por tratamento, ou seja, uma lâmina de $3,68 \mathrm{~mm}$, considerando que a aplicação foi efetuada estritamente na área ocupada pelas mudas.

Para todas as 20 parcelas do experimento foi aplicado em qualquer destas atividades a mesma concentração de qual fosse o produto.

A Tabela 1 mostra as datas de aplicações, os produtos, suas dosagens e finalidades.

Tabela 1. Produtos utilizados durante o período experimental, suas dosagens e respectivas finalidades

\begin{tabular}{|c|c|c|c|}
\hline Data $^{1}$ & Produto & Dosagem & Finalidade \\
\hline $21 / 08$ & $\begin{array}{l}\text { Niphokam } 108^{\circledR} \text { (fertlizante } \\
\text { foliar) }\end{array}$ & 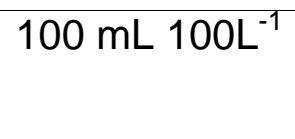 & complementar adubação \\
\hline $21 / 08$ & $\begin{array}{l}\text { Thiophanato Metilico } \\
\text { (fungicida) }\end{array}$ & $250{\mathrm{~g} 100 \mathrm{~L}^{-1}}^{-1}$ & preventivo \\
\hline $25 / 08$ & Clorpirifos (inseticida) & 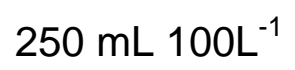 & controlar bicho mineiro \\
\hline 18/09 & $\begin{array}{l}\text { Niphokam } 108^{\circledR} \\
\text { (fertilizante foliar) }\end{array}$ & 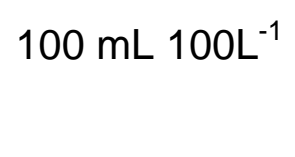 & complementar adubação \\
\hline $18 / 09$ & $\begin{array}{l}\text { Thiophanato Metilico } \\
\text { (funguicida) }\end{array}$ & $250{\mathrm{~g} 100 \mathrm{~L}^{-1}}^{-1}$ & preventivo \\
\hline $02 / 10$ & $\begin{array}{l}\text { Fertirrigação }(\mathrm{MAP} \\
\left.\text { purificado }+\mathrm{KnO}_{3}\right)\end{array}$ & $\begin{array}{l}40 \mathrm{~g} \mathrm{MAP} \\
\text { purificado + } \\
50 \mathrm{~g} \mathrm{KnO}_{3}\end{array}$ & complementar adubação \\
\hline $17 / 10$ & $\begin{array}{l}\text { Niphokam } 108^{\circledR} \\
\text { (fertilizante foliar) }\end{array}$ & 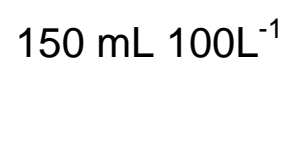 & complementar adubação \\
\hline $30 / 10$ & $\begin{array}{l}\text { Niphokam } 108^{\circledR} \\
\text { (fertilizante foliar) }\end{array}$ & 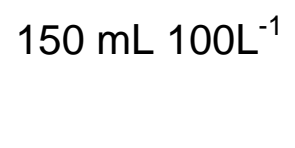 & complementar adubação \\
\hline
\end{tabular}




\subsection{Avaliações}

Conforme descrito anteriormente, as avaliações no experimento foram realizadas em parcelas contendo 175 mudas cada, tendo-se 161 mudas dispostas como bordadura, e 14 mudas para avaliação, localizadas no centro da bancada.

As avaliações neste espaço amostral definido foram de ordem fisiológica, e realizadas de 25 em 25 dias. As variáveis medidas foram altura, diâmetro do caule e área foliar das plantas. A primeira, das quatro avaliações vegetativas previstas, foi efetuada no dia 01/10/2003. A segunda medição foi realizada, conforme mencionado, 25 dias depois, ou seja, no dia 26/10/2003. Uma terceira medida foi realizada no dia 20/11/2003, e a quarta e última coleta de dados foi executada no dia 15/12/2003.

Para a medida da altura, foi utilizada uma régua com precisão de $1 \mathrm{~mm}$, e para o diâmetro do caule foi utilizado um paquímetro digital com precisão de 0,01 mm. A área foliar foi determinada seguindo-se a metodologia proposta por Barros et al. (1973), na qual sugere-se que, com a medição da maior largura e do maior comprimento da folha, seja calculada a área de um retângulo, que posteriormente deve ser corrigida por um fator de forma igual a 0,667. A fórmula sugerida pelos autores citados é expressa pela Eq. 7.

Af $=0,667 \mathrm{Ar}$

em que:

Af - área foliar; $\mathrm{cm}^{2}$;

$\mathrm{Ar}$ - área do retângulo circunscrito à folha, $\mathrm{cm}^{2}$.

Além destas variáveis, ao final do experimento, todas as 14 plantas destinadas às coletas fisiológicas foram destruídas na realização da avaliação da matéria seca. Para isso, separou-se a parte aérea do sistema radicular das 
plântulas úteis de cada parcela. Esse material, após ser preparado, foi depositado em uma estufa de ventilação forçada a $65^{\circ} \mathrm{C}$, e lá permaneceu por 48 horas, tempo que foi suficiente para a estabilização do peso das amostras. 


\section{RESULTADOS E DISCUSSÃO}

\subsection{Variáveis climáticas}

\subsubsection{Temperatura e umidade relativa do ar}

As variáveis climáticas temperatura do ar de bulbo seco e de bulbo úmido foram coletadas ao longo do experimento a partir da utilização de 20 psicrômetros não aspirados, instalados um por parcela, totalizando-se 4 aparelhos por tratamento. Estes dados foram coletados do dia 20/09/2003 ao dia 15/12/2003, totalizando-se 88 dias de coletas, 24 horas por dia, com valores de temperatura em expressos em graus Celsius e de umidade relativa do ar, em percentagem.

Do total dos dados horários de temperatura do ar de cada parcela, separaram-se aqueles referentes aos horários das 8:00, 12:00 e 16:00 horas para realizar-se uma análise estatística, ou seja, para cada dia de coleta, foram utilizados três horários espaçados entre si de 4 horas, sendo um correspondente ao período da manhã, o segundo correspondente à metade do dia e finalmente o terceiro, correspondente ao período da tarde. Por conseguinte, a média horária da umidade relativa do ar em cada parcela, em todos os dias coletados, foi calculada baseando-se nos dados de temperatura do ar de bulbo seco e úmido dos três horários supracitados, com os quais também realizou-se uma análise estatística dos dados. Assim, para ambas as análises estatísticas, de temperatura do ar seco e de umidade relativa do ar, obtiveram-se as médias, para cada um dos três horários, dos 88 dias de coleta, 
tendo-se então para cada uma das 20 parcelas, um valor de temperatura do ar seco e um valor de umidade relativa do ar. A Tabela 2 apresenta os dados médios e a análise estatística realizada.

Tabela 2. Médias das variáveis climáticas temperatura e umidade relativa do ar, medidas nos horários das 8:00, 12:00 e 16:00 horas

\begin{tabular}{lcccccc}
\hline $\begin{array}{c}\text { Tratamentos } \\
\text { (malhas) }\end{array}$ & T8:00* & UR8:00* & T12:00* & UR12:00* & T16:00* & UR16:00* \\
\hline Negra 50\% & 22,4 B & 84,9 A & 31,1 B & $69,6 \mathrm{~B}$ & 30,6 A & $65,6 \mathrm{~A}$ \\
T. refletora 40\% & 22,6 B & 85,9 A & 31,4 A & 71,4 A & 30,5 A & $67,7 \mathrm{~A}$ \\
T. refletora 50\% & 23,4 A & 85,7 A & 31,3 A & 70,4 B & 30,2 A & $66,7 \mathrm{~A}$ \\
T. refletora 60\% & 22,6 B & 86,3 A & 31,0 B & 72,7 A & 30,5 A & $68,7 \mathrm{~A}$ \\
T. refletora 70\% & 22,6 B & 86,1 A & 30,9 B & 72,5 A & 30,5 A & $68,0 \mathrm{~A}$ \\
\hline
\end{tabular}

* Médias seguidas de mesma letra na coluna não diferem entre si pelo teste de Scott-Knott ao nível de $5 \%$ de probabilidade;

** Médias obtidas nos respectivos horários durante 88 dias do período experimental.

Verificou-se ao longo de cada dia que as variáveis climáticas avaliadas apresentaram pequenas variações em função dos tratamentos. Pode-se observar que para a variável T8:00, apenas o tratamento com a malha termorefletora $50 \%$ diferenciou-se significativamente, apresentando maior temperatura média no período avaliado, ao passo que para a variável UR8:00 não houve diferença significativa entre os tratamentos.

Para o período intermediário do dia, o qual foi representado pelas variáveis T12:00 e UR12:00, verificaram-se maiores diferenças significativas, observando-se para a variável T12:00, que as malhas termo-refletoras $40 \%$ e $50 \%$ apresentaram maiores médias nos valores de temperatura do ar, ao passo 
que a malha negra $50 \%$ e as malhas termo-refletoras $60 \%$ e $70 \%$ apresentaram comportamento diferente, com faixa de temperatura inferior. Estes dados referentes a T12:00 confirmam uma tendência que já se esperava, confirmando para o caso das malhas termo-refletoras, que aquelas que mais atenuam a radiação promovem reduções na temperatura do ar. Porém, contrariamente ao esperado, a malha negra 50\% apresentou para este período analisado menor média de temperatura comparativamente ao valor encontrado para a malha termo-refletora $50 \%$.

Para a variável UR12:00, observou-se que as malhas negra $50 \%$ e termo-refletora $50 \%$ diferenciaram-se significativamente das malhas termorefletoras 40\%,60\% e 70\%, verificando-se nas primeiras, ligeira diferença para menos no valor da variável analisada. A temperatura e a umidade relativa do ar possuem comportamentos inversos, ou seja, quando o valor de uma destas variáveis aumenta, o valor da outra diminui. Porém, analisando-se a Tabela 2, verifica-se para o período intermediário do dia que para a malha negra $50 \%$ ocorreu um efeito diferente deste, pois esta malha apresentou a segunda menor média no valor da temperatura do ar, mas também, a menor média no valor de umidade relativa do ar, contrariando as expectativas, que eram de verificar maior valor médio de umidade relativa do ar. Não obstante, para este mesmo tratamento, verifica-se para os períodos das 8:00 e 16:00 horas que o valor médio da temperatura do ar não difere substancialmente daqueles encontrados nos demais tratamentos em um mesmo período, mas, no entanto, os valores médios de umidade relativa do ar nos três períodos avaliados sempre foram menores neste tratamento, efeito este possivelmente causado por alguma particularidade deste material.

Finalmente, para as variáveis T16:00 e UR16:00, verificaram-se para ambas que não houve diferença significativa entre os tratamentos avaliados.

Barros \& Maestri (1974) observaram que o crescimento de folhas em plantas de cafeeiro foi inibido por temperaturas excessivas. 
Medina et al (2002) realizaram experimento comparando o desenvolvimento de mudas cítricas crescidas no interior de uma casa de vegetação, submetidas à malha termo-refletora $50 \%$, com o desenvolvimento de outras mudas cítricas da mesma espécie, crescidas em uma segunda casa de vegetação, porém sem a respectiva malha. Foi verificado que, na casa de vegetação com a presença da malha, a temperatura das folhas era menor, assim como a temperatura do ar também. No entanto, cada casa de vegetação utilizada possuía uma área de $2000 \mathrm{~m}^{2}$, ou seja, a área de cada espaço experimental, correspondente a uma casa de vegetação à qual as mudas foram expostas era grande, e foi possível verificar diferenças nos valores de temperatura medidos.

Nunes et al. $^{1}$, citados por Rena \& Maestri (1987), ao realizarem experimentação constataram que a temperatura constituí-se como um fator de maior importância, se comparado à luz, no controle do crescimento das folhas de cafeeiro.

Entretanto, não foram verificadas nesta experimentação grandes diferenças nos valores médios, tanto para temperatura como para umidade relativa do ar nos cinco tratamentos. Possivelmente, o fato das parcelas terem pequenas áreas, além de estarem todas distribuídas no interior de uma mesma casa de vegetação, contribuiu para que ocorresse maior homogeneidade nestes valores. Pode-se assim concluir que a variável temperatura, neste experimento, possivelmente não foi um fator limitante e de diferenciação para o desenvolvimento destas mudas.

\footnotetext{
${ }^{1}$ NUNES, M.A.; BIERHUIZEN, J.F.; PLOEGMAN,C. Studies on the productivity of coffee. I. Effect of light, temperature and $\mathrm{CO}_{2}$, concentration on photosynthesis of Coffea arabica. Acta Botânica Neerlandica, v.17, p.93-102, 1968.
} 


\subsubsection{Radiação global, radiação fotossinteticamente ativa e saldo de radiação}

Conforme exposto no ítem "material e métodos", as variáveis climáticas radiação global, radiação fotossinteticamente ativa e saldo de radiação foram monitoradas três vezes ao dia, em cinco dias aleatórios, ou seja, em cada dia coletaram-se dados referentes à radiação solar, uma vez no período da manhã, outra num período intermediário do dia e a terceira ao final da tarde, aproximadamente às 17:00 horas. Para tal, acoplaram-se os sensores a um sistema de aquisição de dados CR10X da Campbell Scientific ${ }^{\circledR}$, que foi instalado em uma mochila, garantindo mobilidade em campo nas coletas em cada uma das parcelas.

Para as variáveis radiação global e radiação fotossinteticamente ativa, estabeleceram-se relações entre os dados obtidos dentro e fora de cada uma das 20 parcelas, tendo-se ao final um valor adimensional, representado percentualmente, ou seja, comparando-se os dados internos com os externos a cada parcela pôde-se estimar o quanto cada tratamento atenuou da radiação solar disponível. Desta maneira, obtiveram-se os valores de transmissividade das malhas à radiação global (TRG) e transmissividade das malhas à radiação fotossinteticamente ativa (TRFA) por parcela, tendo-se para cada dia de coleta os dados TRG e TRFA para os momentos da manhã, intermediário ao dia (intermed) e da tarde.

Para analisar estatisticamente estes dados, foram utilizadas as médias simples por tratamento, em cada um dos 3 períodos de coleta de dados, ou seja, considerando-se que o experimento possuía 20 parcelas, obtiveram-se 20 valores de transmissividade para cada período avaliado. A análise destes valores está apresentada na Tabela 3. 
Tabela 3. Média das variáveis transmissividade das malhas à radiação global (TRG) e fotossinteticamente ativa (TRFA), expressas em percentagem, para os momentos da manhã, intermediário do dia e da tarde, segundo os diferentes tratamentos

\begin{tabular}{|c|c|c|c|c|c|c|}
\hline \multirow{3}{*}{$\begin{array}{c}\text { Tratamentos } \\
\text { (malhas) }\end{array}$} & \multicolumn{6}{|c|}{ Valores médios** } \\
\hline & \multirow{2}{*}{\multicolumn{2}{|c|}{ manhã $\tilde{a}^{\star}$}} & TRG & TRFA & $\mathrm{TI}$ & $\mathrm{TI}$ \\
\hline & & & \multicolumn{2}{|c|}{ intermed $^{\star}$} & \multicolumn{2}{|c|}{ tarde* } \\
\hline Negra 50\% & $41,0 \mathrm{~A}$ & $38,7 \mathrm{~A}$ & $45,2 \mathrm{~A}$ & $45,2 \mathrm{~A}$ & $36,2 \mathrm{~B}$ & $38,5 \mathrm{~A}$ \\
\hline T. refletora $40 \%$ & $47,0 \mathrm{~A}$ & $45,2 \mathrm{~A}$ & $65,2 \mathrm{~A}$ & $61,5 \mathrm{~A}$ & $47,7 \mathrm{~A}$ & $44,7 \mathrm{~A}$ \\
\hline T. refletora $50 \%$ & $46,0 \mathrm{~A}$ & $43,2 \mathrm{~A}$ & $48,2 \mathrm{~A}$ & $46,0 \mathrm{~A}$ & $34,5 \mathrm{~B}$ & $33,5 \mathrm{~B}$ \\
\hline T. refletora $60 \%$ & $31,0 \mathrm{~B}$ & $26,5 \mathrm{~B}$ & $32,2 \mathrm{~B}$ & $29,7 B$ & $29,2 \mathrm{~B}$ & $27,0 \mathrm{~B}$ \\
\hline T. refletora $70 \%$ & $27,7 \mathrm{~B}$ & $23,2 \mathrm{~B}$ & $28,0 \mathrm{~B}$ & $25,7 \mathrm{~B}$ & $27,5 \mathrm{~B}$ & $23,7 \mathrm{~B}$ \\
\hline
\end{tabular}

* Médias seguidas de mesma letra na coluna não diferem entre si pelo teste de Scott-Knott ao nível de $5 \%$ de probabilidade;

** Médias obtidas de cinco dias ao longo do experimento, para os 3 períodos de coleta.

Verificou-se para as variáveis TRG e TRFA que nas coletas dos períodos da manhã e intermediário, os tratamentos submetidos à malha negra $50 \%$ e às malhas termo-refletoras $40 \%$ e $50 \%$ não apresentaram diferença significativa, apresentando maior transmissividade. No entanto, diferenciaram-se dos tratamentos submetidos às malhas termo-refletoras $60 \%$ e $70 \%$, que formaram outro grupo sem diferenças significativas e apresentaram menor transmissividade.

Já para o período da tarde, observou-se uma menor diferença em relação aos períodos anteriormente citados, sendo que para a variável TRG, o tratamento submetido à malha termo-refletora $40 \%$ diferenciou-se significativamente dos demais, apresentando maior transmissividade 
comparativamente ao restante dos tratamentos. Finalmente, para a variável TRFA no período da tarde, verificou-se que os tratamentos submetidos às malhas negra $50 \%$ e termo-refletora $40 \%$ não se diferenciaram significativamente, porém, diferenciaram-se dos tratamentos submetidos às malhas restantes, que formaram um grupo de tratamentos que não apresentou diferença significativa, e com menor transmissividade para esta variável avaliada, comparativamente aos tratamentos anteriores.

Os resultados apresentados pela Tabela 3 estão, em geral, em concordância com o que era esperado, pois para ambas as variáveis, nos períodos da manhã e da metade do dia, observa-se que as malhas com menor atenuação da radiação solar, que são as malhas negra 50\% e termo-refletoras $40 \%$ e 50\%, apresentaram maiores valores de transmissividade, comparativamente às malhas termo-refletoras $60 \%$ e $70 \%$, que possuem, por sua vez, características de maior atenuação da radiação. Não diferentemente disso, conforme era esperado, verifica-se também que a malha termo-refletora $50 \%$ possui maior transmissividade comparativamente à malha negra 50\%, devido provavelmente às suas características reflexivas. Este comportamento não foi verificado no período da tarde para ambas as variáveis, possivelmente porque ao entardecer, durante as coletas de dados, ainda existia forte radiação incidente, e no bloco 1, uma parcela com a malha negra 50\% ficou localizada na casa de vegetação de forma que recebia radiação solar direta, ao passo que não houve parcela com a malha termo-refletora 50\% exposta à radiação solar direta para este período de avaliação.

No experimento realizado por Medina et al. (2002), no qual foi comparado o desenvolvimento de mudas cítricas em casas de vegetação separadas, com e sem a presença de malha termo-refletora $50 \%$, os autores verificaram que no ambiente exposto a este tipo de malha, a radiação fotossinteticamente ativa foi menor que aquela medida na casa de vegetação sem a malha termo-refletora $50 \%$, principalmente nos períodos mais quentes do 
dia. Os autores verificaram também que para este tipo de malha a atenuação da radiação fotossinteticamente ativa foi da ordem de $65 \%$.

Em concordância com os resultados encontrados por outros pesquisadores, verificou-se neste experimento para as variáveis TRG e TRFA, nos três períodos do dia analisados, que o valor da transmissividade de cada malha termo-refletora é tanto menor quanto maior é sua percentagem de atenuação da radiação solar, característica concordante com o esperado.

Já para a variável saldo de radiação (SR) não foi possível estabelecer uma relação conforme executado para as duas variáveis anteriores, pois este dado é resultado do balanço da radiação que chega e a que sai do sistema, sendo então dependente do tipo de superfície, neste caso as mudas de cafeeiro. Como nas medidas realizadas fora das parcelas a superfície existente era o próprio solo da casa de vegetação, ou seja, diferente da superfície formada pelo dossel das mudas de cafeeiro, não foi possível trabalhar estes dados comparativamente.

Para esta variável, optou-se por analisar apenas os dados medidos no período da metade do dia (intermediários), pois os dados coletados nos períodos da manhã e da tarde não se apresentaram passíveis de serem trabalhados, devido a incoerências nos valores, possivelmente ocorridas por interferências entre as parcelas.

Para tal, realizaram-se para cada tratamento, em cada dia de coleta, as médias simples por tratamento, tendo-se com estes dados realizado a análise estatística, apresentada pela Tabela 4. 
Tabela 4. Média da variável saldo de radiação $\left(\mathrm{W} \mathrm{m}^{-2}\right)$, avaliada para os diferentes tratamentos, próxima ao horário do meio dia

\begin{tabular}{lccccc}
\hline \multicolumn{1}{c}{$\begin{array}{c}\text { Tratamentos } \\
\text { (malhas) }\end{array}$} & 14/11/03* & 20/11/03* & 25/11/03* & 02/12/03* & 03/12/03* \\
\hline Negra 50\% & 154,8 A & 325,2 A & 264,6 A & 385,5 A & 320,2 A \\
T. refletora 40\% & 143,7 A & 354,6 A & 287,6 A & 381,2 A & $321,5 \mathrm{~A}$ \\
T. refletora 50\% & 148,3 A & 364,3 A & 210,0 A & $322,6 \mathrm{~B}$ & $394,5 \mathrm{~A}$ \\
T. refletora 60\% & 128,1 A & 334,6 A & 132,8 A & $328,7 \mathrm{~B}$ & $314,3 \mathrm{~A}$ \\
T. refletora 70\% & 127,2 A & 324.0 A & 255,7 A & 288,0 B & $327,7 \mathrm{~A}$ \\
\hline
\end{tabular}

* Médias seguidas de mesma letra na coluna não diferem entre si pelo teste de Scott-Knott ao nível de $5 \%$ de probabilidade;

** Médias das quatro repetições para o horário intermediário do dia, obtidas em cinco diferentes datas, ao longo do experimento.

Observando-se a Tabela 4, verifica-se que para a variável saldo de radiação, coletada nos períodos intermediários dos dias avaliados, apenas os dados referentes ao dia 02/12/2003 demonstraram diferenças significativas entre os tratamentos. Para este dia, pode-se notar que os tratamentos submetidos às malhas negra $50 \%$ e termo-refletora $40 \%$ apresentaram os maiores valores de SR, ao passo que as malhas restantes formaram outro grupo, em que não se verificou diferença significativa entre os tratamentos, apresentando menores valores para SR. Para as outras 4 datas avaliadas, não foram encontradas diferenças significativas entre os tratamentos.

Conforme exposto em "materiais e métodos", as coletas das variáveis de radiação solar foram realizadas com a utilização de um datalogger, que era ativado mediante ao acionamento de um botão, permitindo o armazenamento de dados por 10 segundos. Desta forma, as medidas feitas no experimento, em cada período, eram realizadas rapidamente, tendo-se entre o início e o fim um 
tempo utilizado ao redor de 25 minutos. Supõe-se que, possivelmente, a rapidez na realização das medidas desfavoreça o surgimento de interferências que prejudicam as coletas de dados, pois quanto mais rápida a atividade, menores as chances de fatores ambientais, tais como as nuvens, surgirem, o que prejudicaria a qualidade dos dados.

Apesar desta rapidez verificou-se que contrariamente ao esperado, apenas a coleta do dia 02/12/2003 apresentou resultados cujas tendências concordaram parcialmente com as expectativas, ou seja, com as malhas termorefletora $40 \%$ e negra $50 \%$ apresentando maiores valores médios de SR, tendose comportado de acordo com o verificado pela análise estatística, ou seja, sem diferenças significativas. Mas por outro lado, para a malha termo-refletora 50\%, também se esperava um comportamento similar àquele verificado nas malhas citadas anteriormente, tendo-se encontrado, porém, comportamento similar ao observado nas malhas termo-refletoras $60 \%$ e $70 \%$.

A ausência de diferenças entre os tratamentos nas outras quatro datas contrariou as expectativas. Pode-se notar também, além deste comportamento já mencionado, que não houve uma tendência de comportamento para os tratamentos comparando-se as datas avaliadas: verificou-se para o dia 14/11, que o maior valor médio de SR ocorreu no tratamento malha negra $50 \%$; já para os dias 20/11 e 03/12, observa-se que o maior valor médio de SR ocorreu no tratamento malha termo-refletora $50 \%$; finalmente, no dia $25 / 11$ pode-se observar que o maior valor médio de SR ocorreu no tratamento malha termorefletora 40\%. Entretanto, mesmo com estas variações, para todas as datas avaliadas, os maiores valores médios de SR foram verificados nas malhas com atenuação de $40 \%$ e $50 \%$ da radiação solar, ao passo que as malhas com $60 \%$ e 70\% sempre apresentaram menores valores médios de SR.

Algumas interferências ambientais, tais como nuvens, ocorreram durante as medidas, pois a análise estatística dos dados referentes à radiação solar apresentou altos coeficientes de variação para os dias avaliados. Isto contribuiu para que, apesar das grandes diferenças observadas nos valores de SR em 
cada dia avaliado, os tratamentos não apresentassem diferenças significativas, conforme exposto na Tabela 4.

\subsection{Desenvolvimento fisiológico}

As avaliações realizadas durante o experimento consistiram de medidas das variáveis área foliar, altura das plantas e diâmetro do caule nas datas 01/10, 26/10, 20/11 e 15/12 de 2003. As análises de matéria seca da parte aérea, do sistema radicular e matéria seca total foram realizadas apenas ao final do experimento em 16 e 17/12/2003, utilizando-se as 14 mudas úteis de cada parcela que também foram usadas para avaliações de desenvolvimento não destrutivas. As Figuras 9, 10, 11 e 12 ilustram as variáveis fisiológicas medidas em função dos cinco tratamentos utilizados nas datas definidas.

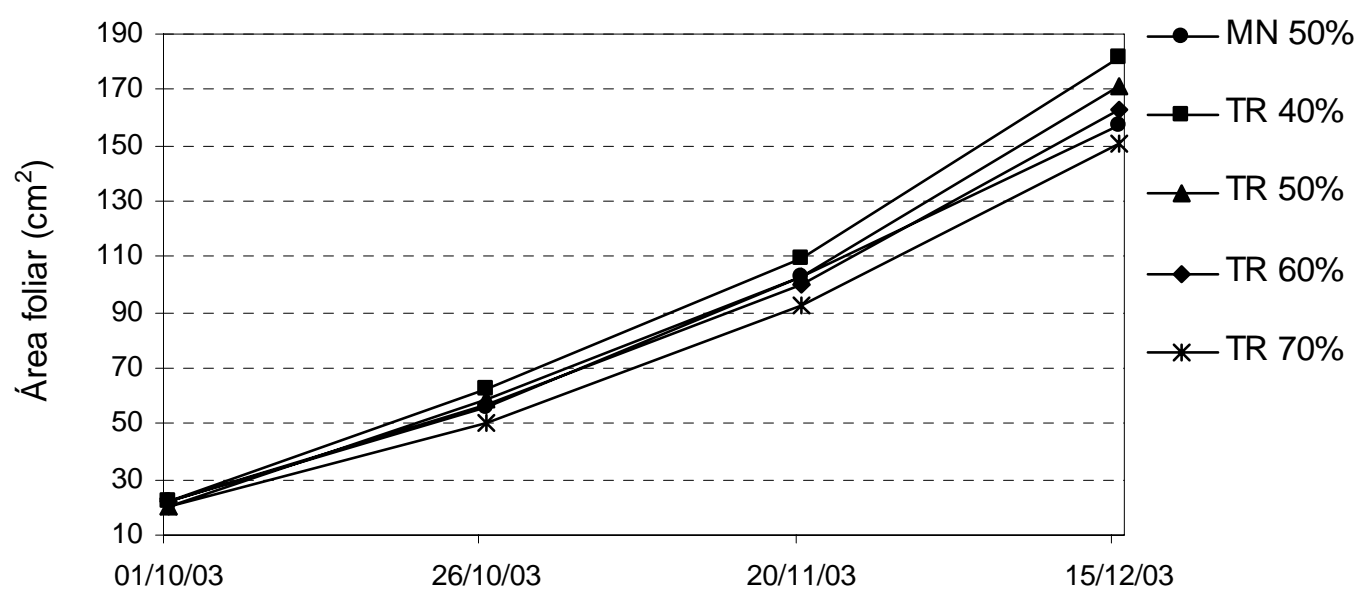

Figura 9 - Áreas foliares médias das mudas de cafeeiro medidas em quatro datas ao longo do experimento para os tratamentos avaliados 


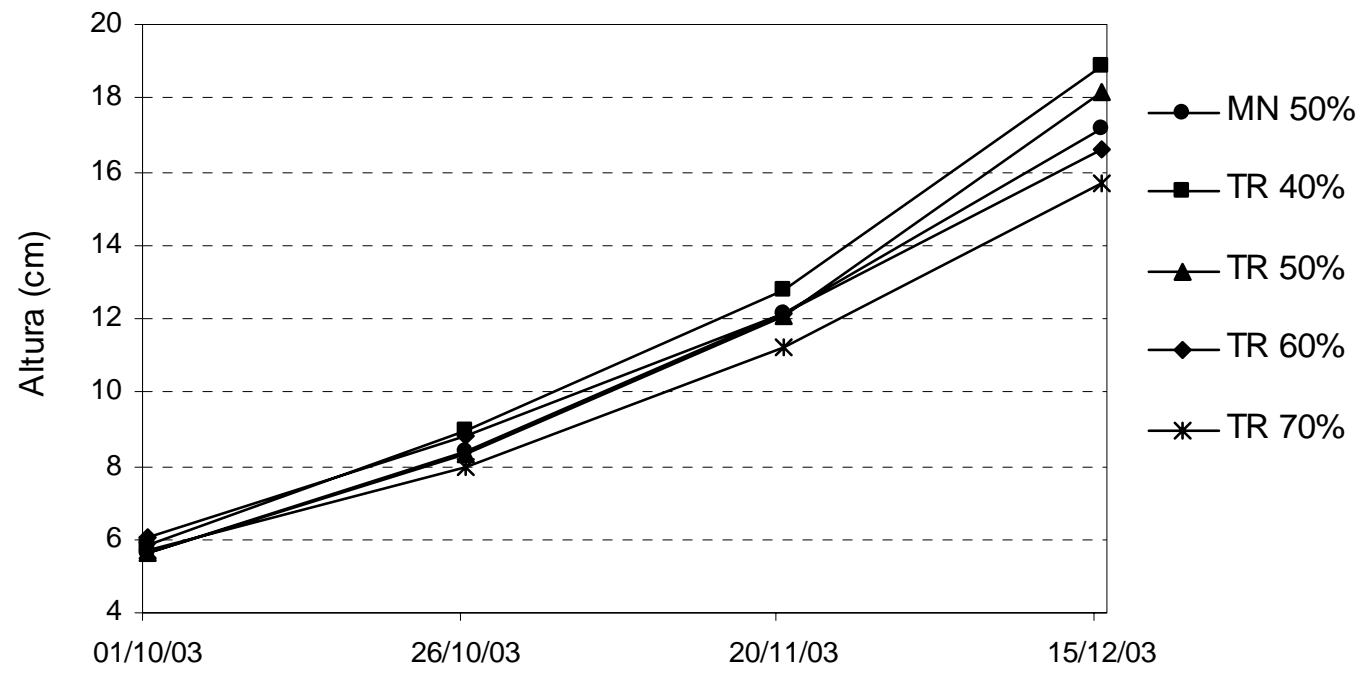

Figura 10 - Alturas médias das mudas de cafeeiro medidas em quatro datas ao longo do experimento para os tratamentos avaliados

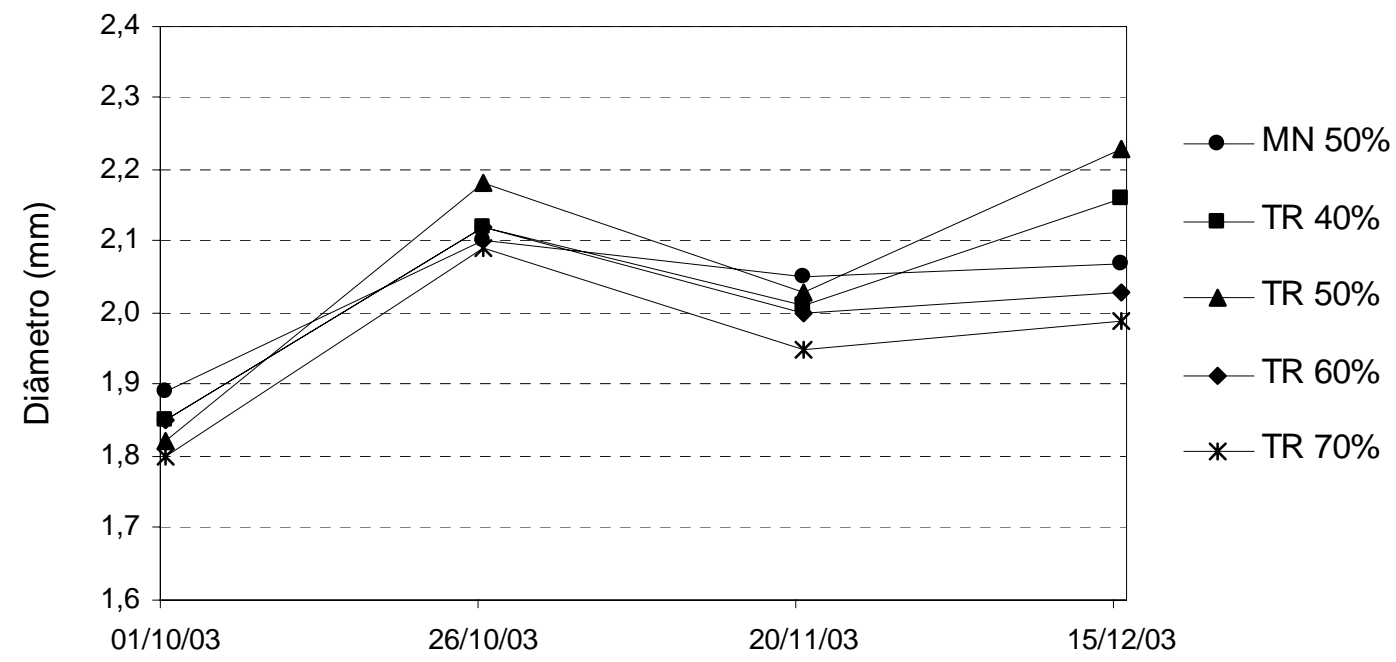

Figura 11 - Diâmetros médios das mudas de cafeeiro medidos em quatro datas ao longo do experimento para os tratamentos avaliados 


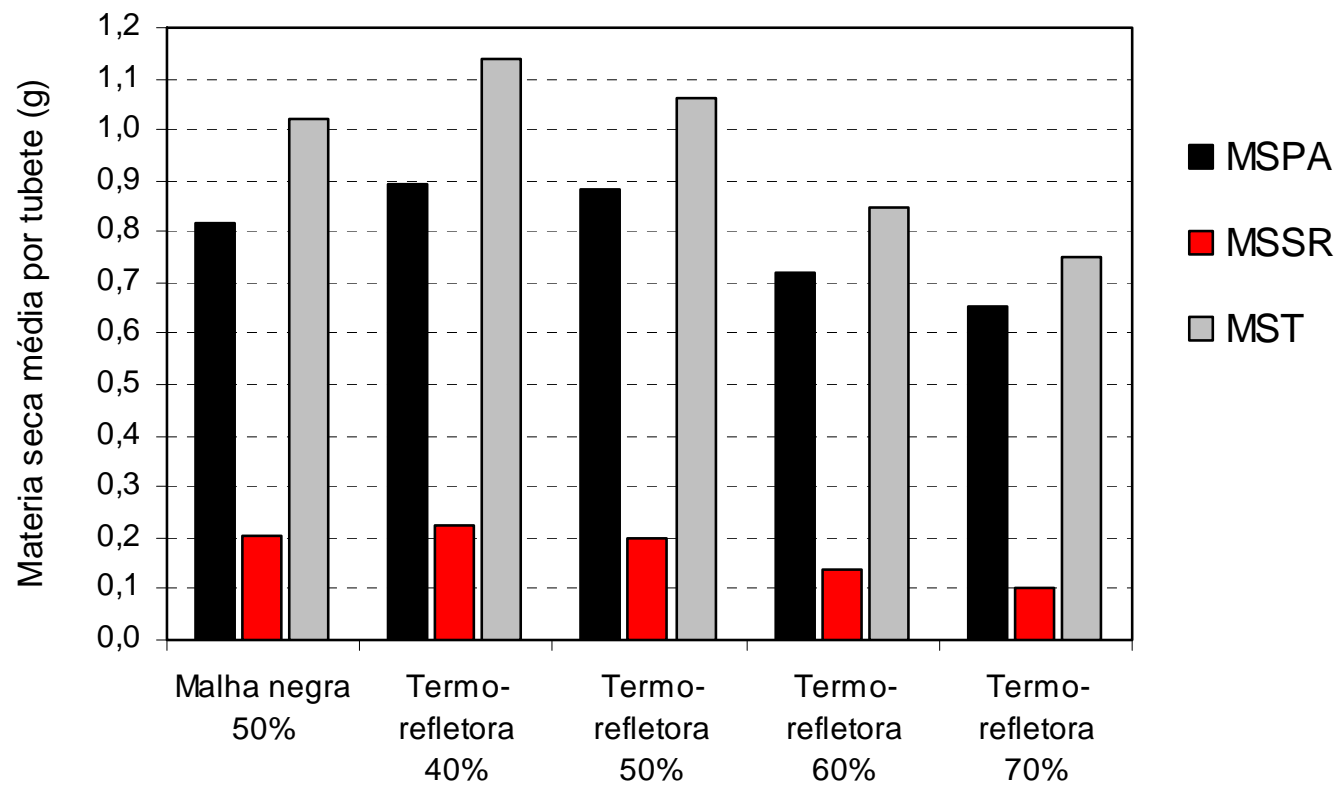

Figura 12 - Valores médios por tubete das matérias secas da parte aérea (MSPA), do sistema radicular (MSSR) e total (MST) avaliados ao final da experimentação

As figuras apresentadas ilustraram o desenvolvimento das mudas nas datas relacionadas, para os cinco tratamentos utilizados no experimento, que foram a malha negra $50 \%$ (MN 50\%) e as malhas termo-refletoras 40\% (TR 40\%), 50\% (TR 50\%), 60\% (TR 60\%) e 70\% (TR 70\%).

Para as variáveis fisiológicas avaliadas, ao final do período experimental verificou-se que a variável área foliar não apresentou diferença significativa entre os tratamentos. Porém, para as variáveis altura da planta e diâmetro do caule, verificou-se diferenças significativas, sendo que as mudas de cafeeiro produzidas sob as malhas termo-refletoras $40 \%$ e $50 \%$ foram superiores àquelas produzidas sob malha negra 50\% e malhas termo-refletoras $60 \% \mathrm{e}$ 70\%. Estes resultados estão apresentados na Tabela 5. 
Tabela 5. Análise estatística das variáveis fisiológicas área foliar, diâmetro do caule e altura de mudas de cafeeiro medidas no final do experimento

\begin{tabular}{lccc}
\hline $\begin{array}{c}\text { Tratamentos } \\
\text { (malhas) }\end{array}$ & Área foliar $\left(\mathrm{cm}^{2}\right)^{\star}$ & Altura $(\mathrm{cm})^{\star}$ & Diâmetro do caule $(\mathrm{mm})^{\star}$ \\
\hline Negra 50\% & $157,07 \mathrm{~A}$ & $17,20 \mathrm{~B}$ & $2,07 \mathrm{~B}$ \\
T. refletora 40\% & 181,18 A & $18,84 \mathrm{~A}$ & $2,16 \mathrm{~A}$ \\
T. refletora 50\% & 171,53 A & $18,15 \mathrm{~A}$ & $2,23 \mathrm{~A}$ \\
T. refletora 60\% & 162,40 A & $16,57 \mathrm{~B}$ & $2,03 \mathrm{~B}$ \\
T. refletora 70\% & 150,72 A & $15,71 \mathrm{~B}$ & $1,99 \mathrm{~B}$ \\
\hline
\end{tabular}

* Médias seguidas de mesma letra na coluna não diferem entre si pelo teste de Scott-Knott ao nível de 5\% de probabilidade;

** Médias de 56 observações.

Embora não tenha sido verificada diferença significativa para a variável área foliar, ao longo do experimento observou-se visualmente que as mudas produzidas sob os tratamentos com a malha termo-refletora $40 \%$ eram mais vistosas e mais robustas, seguidas das mudas crescidas sob a malha termorefletora $50 \%$. Contrariamente, também verificou-se que as mudas que foram submetidas à malha termo-refletora $70 \%$ tiveram seu desenvolvimento comprometido, pois eram visivelmente menores e mais frágeis concordando com o ilustrado (Figuras 9, 10 e 11).

Para as variáveis fisiológicas altura da planta e diâmetro do caule, observou-se em campo desenvolvimento concordante com aquele referenciado na análise estatística (Tabela 5). Pode-se observar pela Figura 11, que a partir da primeira avaliação da variável diâmetro do caule, realizada em 01/10/2003, para a segunda avaliação, feita em 26/10/2003, ocorreu aumento dos diâmetros para todos os tratamentos, naturalmente esperado. Entretanto, pode-se 
observar que houve uma queda do diâmetro, verificada na terceira coleta, realizada em 20/11/2003, com retorno ao crescimento para a quarta coleta, ocorrida em 15/12/2003. Visualmente não foi possível observar estas variações, pois estas diferenças são da ordem de frações de milímetros, impossibilitando a percepção na área experimental.

Paralelamente a este fato, foi verificado que ao longo do desenvolvimento, parte das mudas de todas as parcelas passaram a apresentar desidratação, seguida de um enrijecimento de cor amarronzada nos tecidos do caule a partir do colo da planta (Figura 13). Comportamento similar foi encontrado e descrito por Gervásio (2003), onde foi verificado o surgimento de uma área desidratada também na região do colo da planta, porém seguida de necrose. Após análise para verificação das causas do sintoma, concluiu-se que as mesmas foram decorrentes de fatores abióticos, pois exames fitopatológicos não comprovaram presença de patógenos.

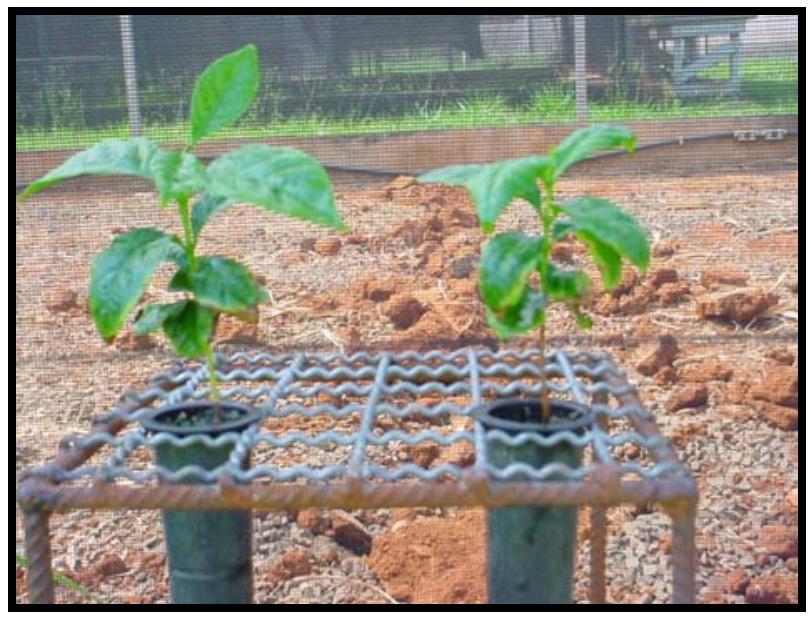

(a)

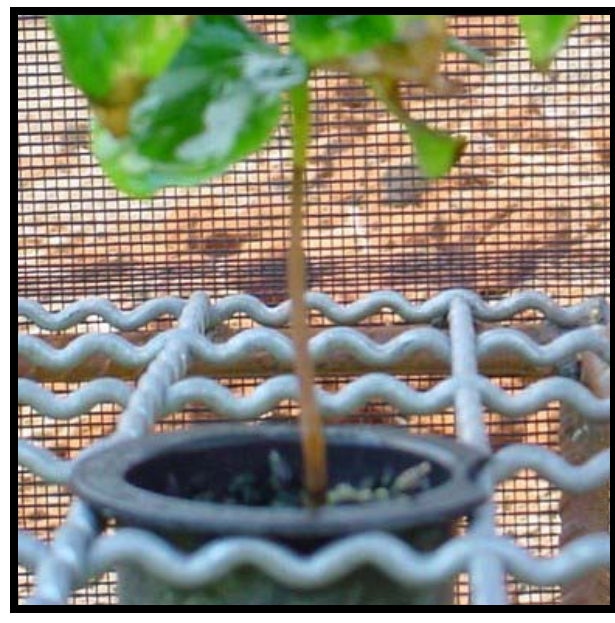

(b)

Figura 13 - Desidratação seguida de enrijecimento na região do colo em mudas de cafeeiro, em estádio avançado (a), e em detalhe (b) 
Nas avaliações de matéria seca, verificou-se que houve diferença significativa entre os tratamentos, observando-se que as mudas de cafeeiro produzidas sob as malhas termo-refletoras $40 \%$ e $50 \%$, e malha negra $50 \%$, desenvolveram-se melhor, tendo acumulado mais matéria seca comparativamente àquelas produzidas sob malhas termo-refletoras $60 \%$ e $70 \%$. Estes resultados estão apresentados na Tabela 6.

Tabela 6. Análise estatística das avaliações da matéria seca da parte aérea, do sistema radicular e total, de mudas de cafeeiro, no final do experimento

\begin{tabular}{|c|c|c|c|c|c|c|}
\hline \multirow{2}{*}{$\begin{array}{c}\text { Tratamentos } \\
\text { (malhas) }\end{array}$} & \multicolumn{6}{|c|}{ Valores médios } \\
\hline & MSPA** $^{* *}$ & $\Delta \mathrm{P}^{*}$ & MSSR $^{\star \star}$ & $\Delta \mathrm{P}^{*}$ & $\mathrm{MST}^{\star \star \star}$ & $\Delta \mathrm{P}^{*}$ \\
\hline Negra $50 \%$ & $11,23 \mathrm{~A}$ & 100,0 & $2,84 \mathrm{~A}$ & 100,0 & $14,07 \mathrm{~A}$ & 100,0 \\
\hline T. refletora $40 \%$ & $12,68 \mathrm{~A}$ & 112,9 & $3,30 \mathrm{~A}$ & 116,2 & $15,98 \mathrm{~A}$ & 113,6 \\
\hline T. refletora $50 \%$ & $12,16 \mathrm{~A}$ & 108,3 & $2,64 \mathrm{~A}$ & 92,9 & $14,80 \mathrm{~A}$ & 105,2 \\
\hline T. refletora $60 \%$ & $9,92 \mathrm{~B}$ & 88,3 & $1,96 \mathrm{~B}$ & 69,0 & $11,88 \mathrm{~B}$ & 84,4 \\
\hline T. refletora $70 \%$ & $9,11 \mathrm{~B}$ & 81,1 & $1,57 \mathrm{~B}$ & 55,3 & $10,68 \mathrm{~B}$ & 75,9 \\
\hline
\end{tabular}

* Variação percentual em relação à malha negra;

** Médias seguidas de mesma letra na coluna não diferem entre si pelo teste de

Scott-Knott ao nível de $5 \%$ de probabilidade;

*** Médias de 56 observações.

Observando-se a Figura 12, pode-se verificar que houve maior produção de matéria seca da parte aérea, do sistema radicular e matéria seca total nas mudas crescidas sob a malha termo-refletora $40 \%$, seguida da malha termorefletora $50 \%$, para a produção de matéria seca da parte aérea e total, verificando-se, porém, para esta malha, que a produção de matéria seca do sistema radicular foi menor que a das mudas crescidas sob malha negra $50 \%$. 
A malha negra $50 \%$ foi, em sequência à malha termo-refletora $50 \%$, o tratamento que apresentou, no geral, melhores resultados para as variáveis avaliadas. Verifica-se também que os piores resultados para estas variáveis foram encontrados nas mudas crescidas sob as malhas termo-refletoras $60 \% \mathrm{e}$ 70\%. Estes resultados podem ser observados na Tabela 6 nas colunas complementares que estão ilustrando, em termos percentuais, as variações na produção de matéria seca para cada uma das variáveis avaliadas, em relação à malha negra $50 \%$.

Durante o experimento não foi possível observar visualmente estas variações com detalhamento que a Figura 12 apresenta. Porém, pôde-se verificar que as mudas crescidas sob a malha termo-refletora $40 \%$ possuíam melhor desenvolvimento em sua parte aérea, ao passo que aquelas produzidas sob o maior nível de atenuação de radiação, ou seja, sob a malha termorefletora $70 \%$, eram piores neste quesito.

Resultados similares foram encontrados por Paiva (2001), Silveira \& Maestri (1973) e Maestri \& Gomes (1961), em cujos trabalhos foi observado que mudas de cafeeiro produzidas em ambiente com sombreamento ao redor de 50\% apresentaram maior média de área foliar, altura e produção de matéria seca, ao passo que condições de excesso de sombra ou de luminosidade prejudicaram o desenvolvimento das mesmas.

\subsection{Considerações finais}

Alguns comportamentos observados ao longo da experimentação são possivelmente decorrentes de fatores que foram verificados após o início das atividades, e em muitos casos a situação não pode ser revertida. Desta forma, serão apresentados alguns comentários sobre problemas verificados durante o experimento, com algumas sugestões, visando-se aperfeiçoar outras experiências que poderão ser realizadas nesta linha de pesquisa, 
considerando-se aqui tanto a produção de mudas de cafeeiro em tubetes como o ambiente no qual estas mudas estarão submetidas.

Este experimento foi instalado no interior de uma casa de vegetação com uma área interna de $112 \mathrm{~m}^{2}$, na qual os quatro blocos experimentais foram instalados em duas linhas, havendo dois blocos por linha, distanciados de 1,40 m. Cada parcela, representada por uma bancada, possuía área de 1,68 $\mathrm{m}^{2}$, e era distanciada da outra parcela vizinha, na mesma linha, de 0,55 m, conforme exposto em "materiais e métodos"

Pôde-se verificar por meio da análise estatística dos dados referentes à temperatura e umidade relativa do ar, que as diferenças entre os valores médios encontradas em cada condição avaliada foi muito pequena. Para o caso da temperatura do ar, verificou-se para a maioria dos casos diferença da ordem de menos de $1^{\circ} \mathrm{C}$ de tratamento para tratamento. Para os dados de umidade relativa do ar, devido às pequenas variações na temperatura, também foram verificadas pequenas diferenças. É provável que tanto as pequenas dimensões de cada parcela, como a proximidade entre elas, tenha permitido que a advecção lateral e a própria circulação do ar no interior da casa de vegetação, que era aberta nas laterais, impedissem que variações mais amplas pudessem ocorrer. Para solucionar este problema, o desenvolvimento de um experimento mais trabalhoso e oneroso possivelmente apresentaria resultados diferentes: separar-se-ia cada tratamento em uma casa de vegetação, localizando-se as mesmas próximas umas das outras, evitando-se desta forma grandes disparidades de condições de trabalho.

Outro problema verificado foi quanto à distribuição dos blocos na área experimental. $\mathrm{Na}$ configuração de distribuição dos blocos, que era em duas linhas, surgiu um problema de interferência entre as parcelas experimentais, pois nos períodos do dia correspondentes à manhã e à tarde, ou seja, ao nascer e ao pôr do sol, cada parcela que estava localizada imediatamente em seqüência à outra era sombreada, e este efeito ia sendo gradativamente 
eliminado ao longo de cada dia, no período da manhã, conforme o tempo passava, e contrariamente, este efeito ia se acumulando ao entardecer.

Este experimento teve como objetivo principal avaliar o efeito de diferentes malhas, com diferentes percentagens de atenuação da radiação solar, no desenvolvimento de mudas de cafeeiro produzidas em tubetes. No entanto, de acordo com o exposto, as interferências encontradas entre parcelas possivelmente prejudicaram em parte os resultados para cada malha utilizada, mascarando-se em parte alguns efeitos destes materiais quanto à atenuação da radiação que cada um realmente possui como característica.

Uma possível solução, exclusiva para este problema, seria a instalação deste experimento com os blocos seguindo a mesma configuração, porém, em uma casa de vegetação construída no sentido norte-sul. Desta maneira, devido à separação lateral entre linhas ser de $1,40 \mathrm{~m}$, as interferências seriam, provavelmente, bastante atenuadas, de forma que é possível que maiores variações, tanto climatológicas quanto fisiológicas, poderiam ser verificadas. 


\section{CONCLUSÕES}

Nas condições em que o experimento foi conduzido, foi possível concluir que:

1) No geral, as malhas termo-refletoras $40 \%$ e $50 \%$ e a malha negra $50 \%$ propiciaram os melhores resultados em relação à matéria seca, à altura e ao diâmetro do caule das mudas, comparativamente às malhas termo-refletoras $60 \%$ e $70 \%$;

2) As diferenças entre as transmissividades das malhas termo-refletoras foram verificadas em todas as avaliações realizadas, observando-se que quanto menor a atenuação da radiação solar, maior a transmissividade da malha;

3) Em geral a malha termo-refletora 50\% apresentou maior transmissividade que a malha negra 50\%;

4) As malhas não afetaram significativamente a temperatura e a umidade relativa do ar nas parcelas, principalmente nos períodos da manhã e da tarde. 
ANEXO 


\section{ANEXO: BARRA DE IRRIGAÇÃO SEMI-AUTOMATIZADA}

\section{A.1 Desenvolvimento do sistema de irrigação}

Desenvolveu-se uma barra de irrigação, confeccionada em ferro, capaz de deslocar-se longitudinalmente na casa de vegetação em ambos os sentidos. O mecanismo de sustentação foi composto por dois trilhos metálicos, fixados um em cada lateral, a uma altura de 2,00 m, distanciados de 6,30 m, espaço este correspondente ao vão livre existente entre os pontos de apoio.

A parte hidráulica da barra foi composta por tubos de PVC rígido com diâmetro de 3/4 de polegada e comprimento de $4 \mathrm{~m}$, tendo apenas um ponto de alimentação de água. O sistema foi projetado para irrigar duas linhas distanciadas de 3,6 m. Foram instalados em série, em cada linha de irrigação, dois emissores tipo "leque", série AD-IA (anti deriva - indução de

ar) da Magno Cerâmica ${ }^{\circledR}$, com vazão nominal de $1,8927 \times 10^{-5} \mathrm{~m}^{3} \mathrm{~s}^{-1}(0,3$ gal $\min ^{-1}$ ). Este sistema de irrigação foi ajustado para trabalhar a 0,95 $\mathrm{m}$ de distância em relação à superfície irrigada. A pressão de serviço foi fixada em 275 kPa (28 mca), mantida assim por uma válvula reguladora de pressão instalada no tubo de PVC anteriormente aos bicos.

Sob um dos trilhos laterais de sustentação da barra foi fixado a 0,05 m um outro trilho com comprimento de $17,5 \mathrm{~m}$, ou seja, o comprimento da estufa. Este trilho, denominado comercialmente de Standard, serviu para que uma mangueira de borracha flexível, condutora da água de irrigação pudesse ser instalada de forma a deslocar-se juntamente com a barra, sendo tracionada por ela. A mangueira, de 3/4 de polegada de diâmetro, foi fixada em seis pequenos carrinhos, cada qual com quatro rolamentos, responsáveis pela movimentação desta, sem comprometer o deslocamento da barra. $O$ conjunto moto-bomba utilizado para pressurização do sistema era acionado 
através de um painel eletrônico de comando marca Galcon ${ }^{\circledR}$, responsável pelo instantâneo acionamento da moto-bomba, juntamente ao acionamento de uma válvula solenóide elétrica instalada anteriormente à mangueira flexível condutora de água.

Os trilhos de sustentação da barra de irrigação serviram também como meio de suporte para a tração do equipamento. Na mesma lateral onde foi instalada a mangueira de água, acoplou-se um conjunto moto-redutor, composto por um motor elétrico trifásico $(220 \mathrm{~V})$ de $60 \mathrm{~Hz}$ e um redutor de 1:800. A Figura A1 ilustra alguns detalhes do sistema de irrigação.

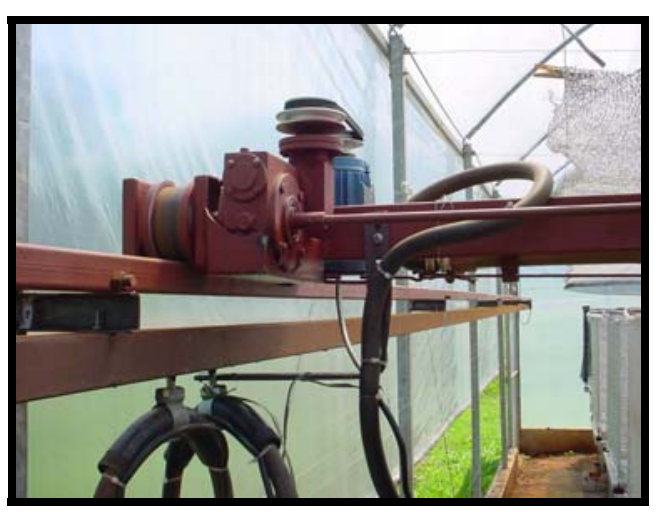

(a)

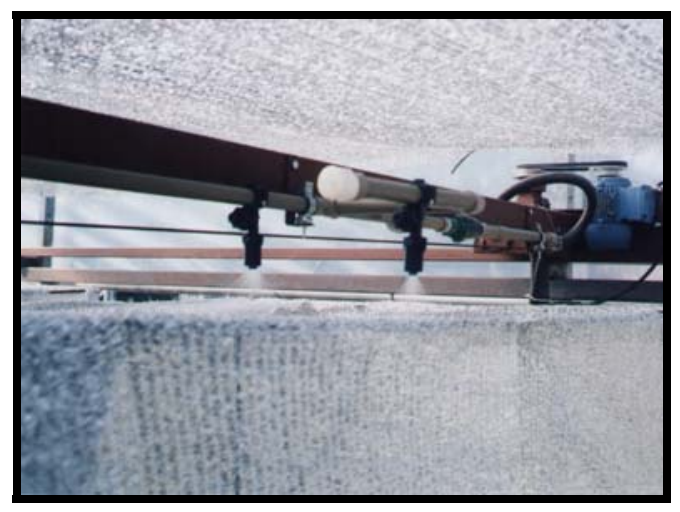

(c)

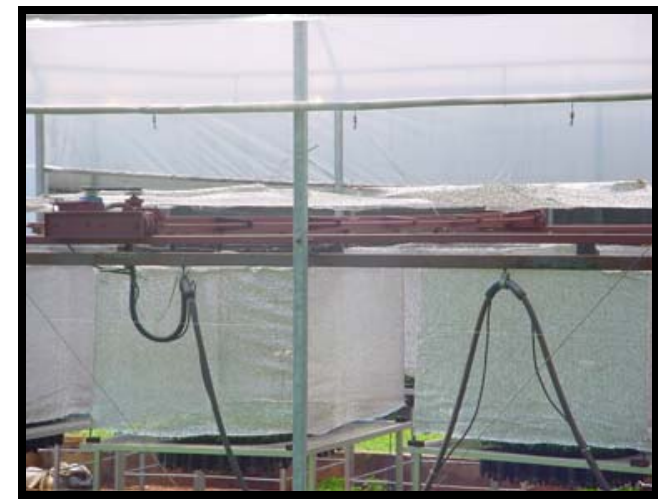

(b)

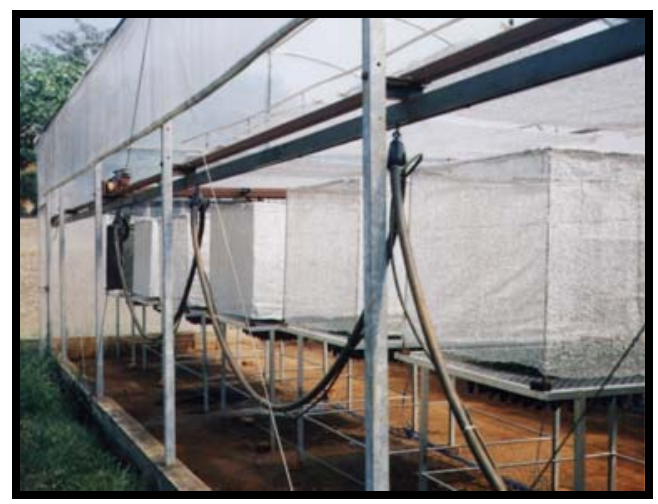

(d)

Figura A1 -Trilhos de apoio da barra e mangueira, e moto-redutor (a); barra de irrigação inteira (b); detalhe da parte hidráulica e bicos instalados em série em funcionamento (c); mangueira acompanhando a barra em funcionamento (d) 


\section{A.2 Automatização do sistema de irrigação}

O desenvolvimento de um sistema de irrigação semi-automatizado foi realizado para possibilitar alta precisão nas regulagens para aplicação das lâminas de irrigação em um experimento com delineamento experimental de 5 tratamentos com 4 repetições. Cada tratamento possuiu uma condição de sombreamento, avaliando-se o desenvolvimento de mudas de cafeeiro submetidas a este ambiente. As malhas utilizadas no experimento foram: malha negra $50 \%$, utilizada como tratamento controle, e as malhas termorefletoras 40\%, 50\%, 60\% e 70\%.

Para a irrigação, cada lâmina aplicada foi idêntica para todas as parcelas durante todo o período experimental, e foi calculada com base na adoção de duas metodologias distintas. A primeira foi utilizada de 14/08/2003, data que caracterizou o início do experimento, a 25/09/2003, segundo recomendação feita por Guimarães et al. (1998). Esta metodologia estabeleceu a aplicação de 2,5 mm diários até o surgimento do primeiro par de folhas definitivo, estabelecido pelo dia 08/09/2003. A partir desta data até 25/09/2003 aplicaram-se diariamente 4,5 mm. A partir daí a metodologia foi modificada, iniciando-se a utilização de um processo gravimétrico para estimar a evapotranspiração diariamente, utilizando-se de uma balança com precisão de 0,01 g, na qual uma amosta de tubetes era utilizada como base para cálculo da evapotranspiração. Este processo, mais apurado e preciso, foi então adotado a partir desta data até a finalização do experimento. As irrigações foram realizadas em geral duas vezes ao dia, com exceção para alguns dias em que a demanda evapotranspirativa foi baixa, adotando-se aí apenas uma irrigação por dia ou nenhuma.

Os 4 blocos com distribuição casualizada foram dispostos em duas fileiras de 2 blocos com 10 parcelas cada, no sentido longitudinal da casa de vegetação, espaçadas de 1,40 m entre fileiras e 0,55 m entre parcelas. Cada 
parcela foi composta por uma bancada de $1,20 \mathrm{~m} \times 1,40 \mathrm{~m}$, com mudas dispostas ocupando uma área de 1,00 m x 0,55 m, ou seja, 0,55 m².

A automatização do sistema de irrigação foi realizada com um inversor de freqüência de marca $\mathrm{Weg}^{\circledR}$, série CFW-08, instalado em um painel de comando, onde manualmente os ajustes foram realizados, assim como o acionamento do sistema. Seu desligamento era automático, pois conectados ao inversor estavam o moto-redutor e dois fins de curso, cada um alocado em ponto previamente determinado numa e na outra extremidade da casa de vegetação, pontos estes de interrupção do funcionamento do sistema. $O$ conjunto moto-bomba era acionado independentemente da barra de irrigação. A Figura A2 ilustra alguns detalhes do painel de comando para acionamento do sistema de irrigação.

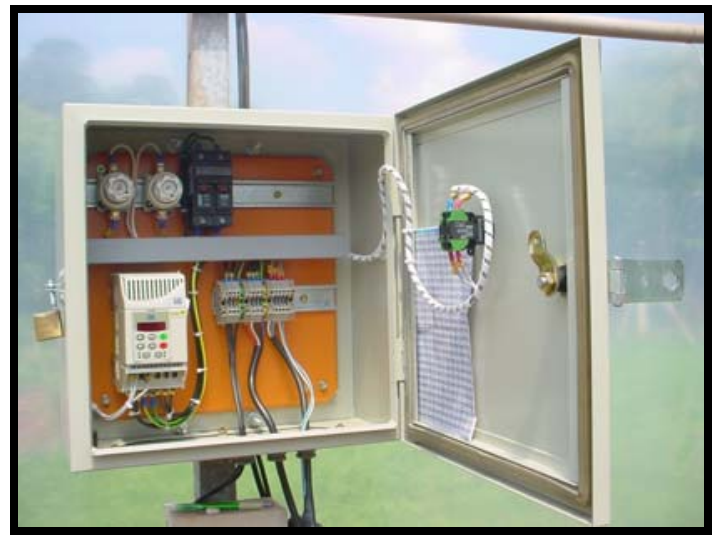

(a)

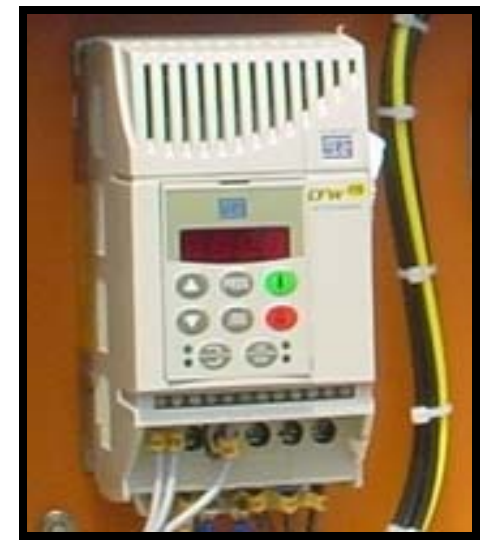

(b)

Figura A2 - Painel de comando do sistema de irrigação em barra (a); detalhes do inversor de freqüência utilizado na semi automatização (b)

\section{A.3 Avaliação do sistema de irrigação}

O sistema de irrigação foi avaliado em duas etapas, tendo como principal objetivo determinar a uniformidade de aplicação das lâminas de 
irrigação. A primeira etapa foi desenvolvida no Laboratório para Avaliação de Sistemas para Aplicação de Produtos Fitossanitários (LASAPF), no Departamento de Engenharia Rural, setor de Máquinas e Mecanização Agrícola. Esta etapa constituiu-se pela avaliação da distribuição linear do emissor de pulverização tipo "leque" utilizado durante o experimento, e visouse analisar a distribuição transversal destes emissores de pulverização. $O$ equipamento utilizado no teste constitui-se por uma bancada com dimensões $3,5 \mathrm{~m} \times 3,0 \mathrm{~m}$, com regulagem para a altura da barra de pulverização. É composta por divisores paralelos na superfície onde a água é pulverizada, distanciados de 0,025 m, funcionando de forma que o volume de água pulverizado fica coletado em uma proveta própria, individualizada. A pressão utilizada no teste foi de $275 \mathrm{kPa}$ ( $28 \mathrm{mca}$ ) e a altura de instalação do emissor foi de 0,95 $\mathrm{m}$ em relação à superfície, as mesmas utilizadas na barra de irrigação durante o experimento. A Figura A3 ilustra alguns detalhes deste equipamento utilizado para o teste.

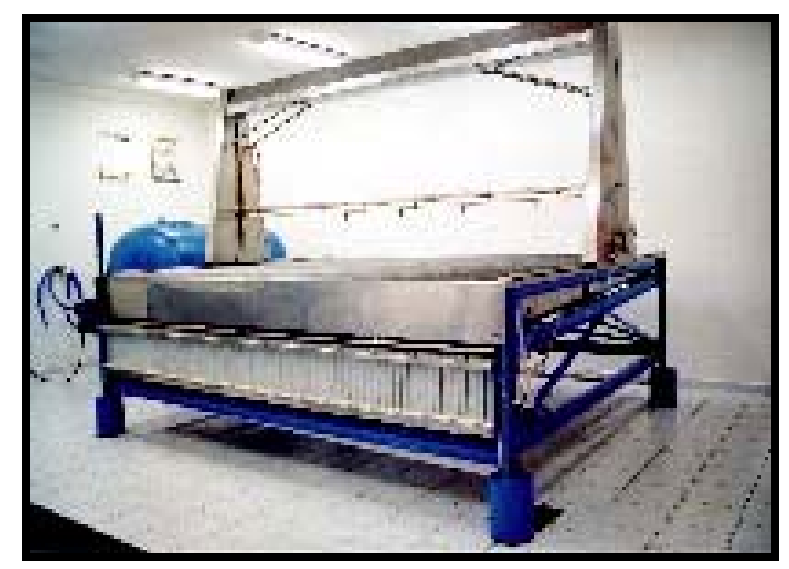

Figura A3 - Bancada para análise da distribuição transversal do emissor tipo "leque"

O importante nesta avaliação foi a constatação de que o jato em forma de leque pulverizado por um único emissor na altura especificada abrangia uma largura máxima de 1,75 m (0,87 m aproximadamente para cada lado, 
considerando como posição zero aquela perpendicular ao plano horizontal da bancada e bem abaixo do emissor).

Contudo, no experimento a largura de interesse a ser irrigada foi de $1,00 \mathrm{~m}$, ou seja, $0,50 \mathrm{~m}$ para cada lado, pois esta era a largura máxima com mudas, considerando as mudas amostrais e a bordadura. Assim, no ponto perpendicular ao plano horizontal da bancada e imediatamente abaixo dos emissores da barra de irrigação tinha-se para cada lado cerca de 0,15 m com plantas que representaram o espaço amostral, totalizando um espaço amostral com 0,30 m de largura. A Figura A4 ilustra o croqui de vista frontal da barra utilizada no experimento e a largura máxima abrangida em cada linha de irrigação.

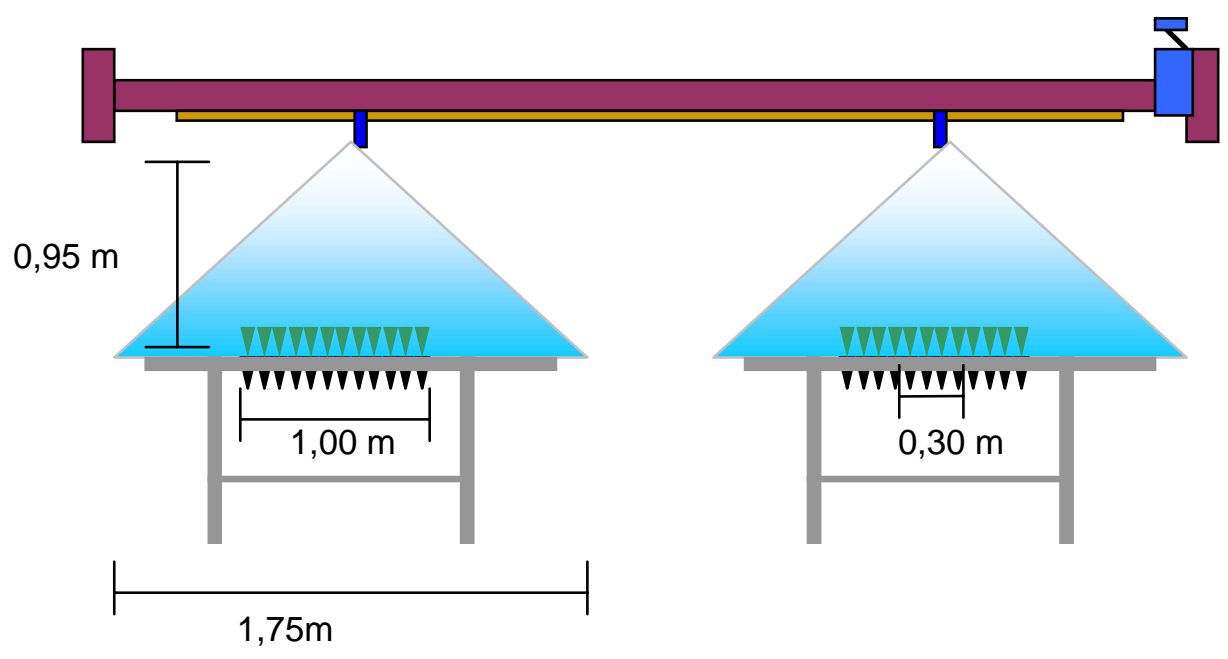

Figura A4 - Linha de irrigação abrangida pelos emissores tipo "leque"

Os resultados do teste Largura da faixa de aspersão $x$ Coeficiente de variação (CV\%) para o emissor tipo "leque" utilizado realizados na bancada para análise de emissores estão ilustrados na Figura A5. 


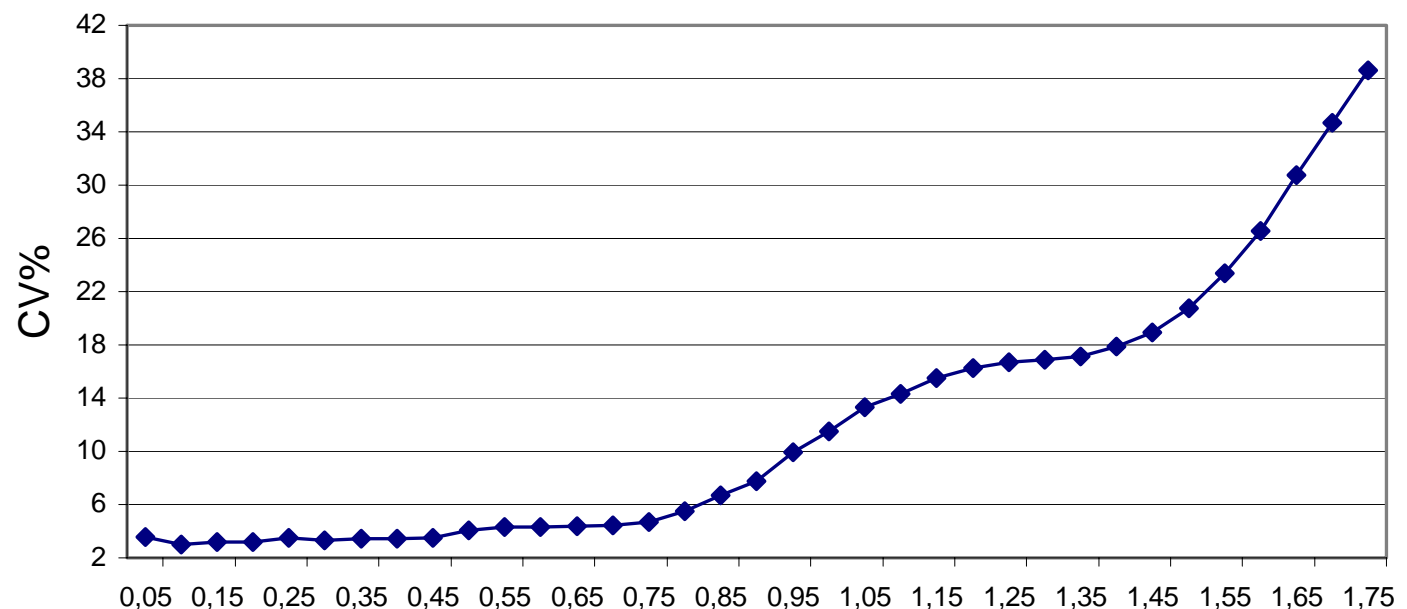

Largura (m)

Figura A5 - Gráfico ilustrativo da largura (m) x coeficiente de variação (CV\%) para o emissor tipo "leque"

De acordo com este teste pôde-se verificar que para a largura total com mudas, que foi de $1,00 \mathrm{~m}$, e para a largura ocupada pelas mudas amostrais, que foi de $0,30 \mathrm{~m}$, verificaram-se valores de CV iguais a $11,47 \%$ e $3,34 \%$, respectivamente.

A segunda etapa da avaliação foi desenvolvida já na barra de irrigação dentro da casa de vegetação. Utilizando uma bandeja metálica com dimensões 0,900 m x 0,675 $\mathrm{m}\left(0,6075 \mathrm{~m}^{2}\right)$, colocada a 0,95 $\mathrm{m}$ de uma das linhas de dois emissores dispostos em série, coletaram-se os volumes de água pulverizados nesta área, regulando-se o inversor de freqüência previamente de tal forma que a barra entrou em funcionamento em freqüências que variaram de $35 \mathrm{~Hz}$ a $95 \mathrm{~Hz}$, aumentando-se este valor de 5 em $5 \mathrm{~Hz}$. Para cada freqüência avaliada foram feitas 3 repetições, e a partir dos volumes coletados obteve-se a média; dividindo-se cada volume médio pela área de $0,6075 \mathrm{~m}^{2}$, determinaram-se as respectivas lâminas de irrigação correspondentes às freqüências avaliadas. Os resultados desta avaliação são apresentados na Tabela $A 1$. 
Tabela A1. Resultados da avaliação da barra de irrigação.

\begin{tabular}{cccccc}
\hline $\begin{array}{c}\text { Freqüência } \\
(\text { Hertz })\end{array}$ & $\begin{array}{c}\text { repetição 1 } \\
(\mathrm{L})\end{array}$ & $\begin{array}{c}\text { repetição 2 } \\
(\mathrm{L})\end{array}$ & $\begin{array}{c}\text { repetição 3 } \\
(\mathrm{L})\end{array}$ & $\begin{array}{c}\text { Média }^{1} \\
(\mathrm{~L})\end{array}$ & $\begin{array}{c}\text { Lâmina }^{2} \\
(\mathrm{~mm})\end{array}$ \\
\hline 35 & 1,68 & 1,69 & 1,78 & 1,717 & 2,826 \\
40 & 1,46 & 1,48 & 1,51 & 1,483 & 2,442 \\
45 & 1,29 & 1,29 & 1,30 & 1,293 & 2,129 \\
50 & 1,19 & 1,17 & 1,19 & 1,183 & 1,948 \\
55 & 1,03 & 1,02 & 1,03 & 1,027 & 1,690 \\
60 & 0,98 & 0,98 & 0,98 & 0,980 & 1,613 \\
65 & 0,90 & 0,90 & 0,91 & 0,903 & 1,487 \\
70 & 0,83 & 0,84 & 0,84 & 0,837 & 1,377 \\
75 & 0,78 & 0,78 & 0,78 & 0,780 & 1,284 \\
80 & 0,73 & 0,74 & 0,72 & 0,730 & 1,202 \\
85 & 0,71 & 0,69 & 0,67 & 0,690 & 1,136 \\
90 & 0,63 & 0,64 & 0,65 & 0,640 & 1,053 \\
95 & 0,61 & 0,61 & 0,63 & 0,617 & 1,015 \\
\hline
\end{tabular}

${ }^{1}$ Média das repetições 1, 2 e 3;

${ }^{2}$ Lâmina calculada tomando como base o volume médio.

Verificou-se que para cada freqüência avaliada ocorreu uma pequena variação nos volumes coletados em cada repetição. Com os dados de freqüência e a respectiva lâmina, obteve-se o gráfico ilustrado pela Figura A6. 


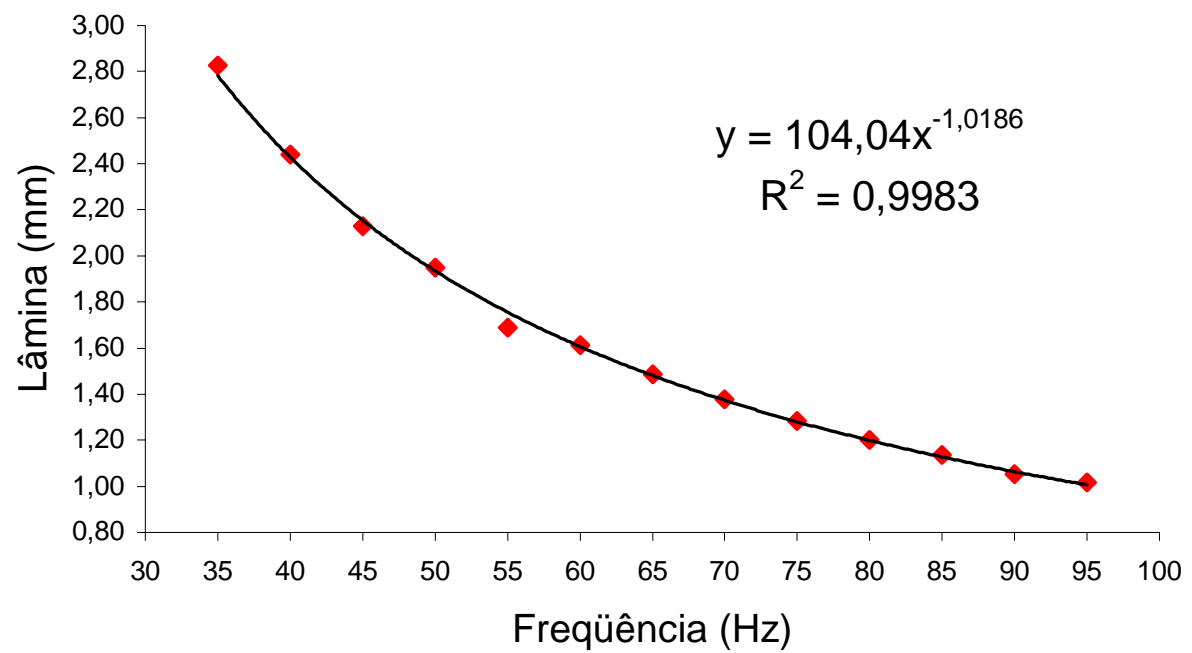

Figura A6 - Gráfico ilustrativo da lâmina coletada em função da freqüência de operação da barra de irrigação

Com estes pontos obtidos, ajustou-se a seguinte equação:

$\mathrm{LAM}=104,04(\mathrm{FREQ})^{-1,0186} \quad\left(\mathrm{R}^{2}=0,9983\right)$

Em que:

LAM - lâmina de irrigação, mm;

FREQ - freqüência ajustada, Hertz.

Dessa forma, observa-se que este sistema de irrigação possibilita a aplicação de lâminas muito precisas, considerando que o inversor de freqüência utilizado possui uma precisão de $0,01 \mathrm{~Hz}$. Para a utilização com o conjunto moto-redutor empregado, recomenda-se freqüências que variam de 35 a $95 \mathrm{~Hz}$, observando-se então que há possibilidade deste sistema ser operado aplicando por ciclo de irrigação lâminas de 2,826 mm a 1,015mm, respectivamente. Nota-se que a faixa de lâmina aplicada por ciclo é estreita, fato este explicado pela intensa redução utilizada no sistema, ou seja, de 
1:800. A baixa intensidade de aplicação (IA) deste sistema evita perdas por escoamento e percolação, o que se constitui em uma vantagem tendo em vista que os recipientes irrigados eram tubetes, com pequena área para coleta.

\section{A.4 Operação do sistema de irrigação}

O sistema de irrigação era ativado em geral diariamente, aplicando-se a mesma lâmina para todas as parcelas.

Seguindo-se este padrão, nos momentos em que se ia irrigar após terse determinado a lâmina de irrigação, acionava-se manualmente o conjunto responsável pela pressurização do sistema de irrigação, por meio de um painel de comando que enviava simultaneamente um sinal para a motobomba e para uma válvula elétrica solenóide. Após isso, regulava-se diretamente no inversor de freqüência a freqüência desejada, a qual que correspondia à lâmina que se necessitava aplicar. 


\section{REFERÊNCIAS BIBLIOGRÁFICAS}

BARROS, R.S.; MAESTRI, M.; VIEIRA, M. et al. Determinação da área de folhas do café (Coffea arabica L. cv. 'Bourbon Amarelo'). Revista Ceres, v.20, n.107, p.44-52, 1973.

BARROS, R.S.; MAESTRI, M. Influência dos fatores climáticos sobre a periodicidade de crescimento vegetativo do café (Coffea arabica L.). Revista Ceres, v.20, p.268-279, 1974.

CARDOSO, A.P.S. Café: cultura e tecnologia primária. Lisboa: Instituto de Investigação Científica Tropical, 1994. 169p.

CARVALHO, F. Estudo da atividade da nitrato redutase em mudas de café (Coffea arabica L.), cultivadas à meia sombra e a pleno sol e sob as formas nítrica e amoniacal de adubação nitrogenada. In: CONGRESSO BRASILEIRO DE PESQUISAS CAFEEIRAS, 3., Curitiba, 1975. Anais. Rio de Janeiro: IBC; GERCA, 1975. p.208.

CORDEIRO, A.T.; RENA, A.B.; MENDES, L.F. et al. Atividade da redutase do nitrato em plantas jovens e adultas de Coffea arabica L., à luz e na obscuridade. In: CONGRESSO BRASILEIRO DE PESQUISAS CAFEEIRAS, 11., Londrina, 1984. Anais. Rio de Janeiro: IBC; GERCA, 1984. p.77-79. 
FALEIROS, R.R.S.; MELO, W.J.; CARVALHO, F. et al. Atividade da nitrato redutase e desenvolvimento de mudas de Coffea arabica L. (café). Científica, v.3, p.277-283, 1975.

GERVÁSIO, E.S. Efeito de lâminas de irrigação e doses de condicionador, associadas a diferentes tamanhos de tubetes, na produção de mudas de cafeeiro. Piracicaba, 2003. 105p. Tese (Doutorado) - Escola Superior de Agricultura "Luiz de Queiroz", Universidade de São Paulo.

GONÇALVES, J.C.; THOMAZIELLO, R.A. Produção de mudas de café. Campinas: CATI, s.d. 27p.

GUIMARÃES, P.T.G.; CARVAlHO, M.M.; MENDES, A.N. et al. Produção de mudas de café: coeficientes técnicos da fase de viveiro. Informe Agropecuário, v.14, n.162, p.5-10, 1989.

HAFERS, L.S.; SAES, S.M. Brasil, Colômbia e México: tecnologia e coordenação. In: FNP CONSULTORIA \& COMÉRCIO. AGRIANUAL 2002: anuário da agricultura brasileira. São Paulo, 2002. p.215-219.

HANAN, J. J. Greenhouses: advanced technology for protected horticulture. Boca Raton: CRC Press, 1998. 684p.

INSTITUTO CAMPINEIRO DE ENSINO AGRÍCOLA. Cultura do café. Campinas, 1973. 84p.

MAESTRI, M; GOMES, F.R. Crescimento de mudas de café (Coffea arabica L. cv. 'Bourbon') sob diferentes níveis de luz. Revista Ceres, v.11, p.265-271, 1961. 
MATIELLO, J. B. O café: do cultivo ao consumo. São Paulo: Globo, 1991. 320p. (Coleção do Agricultor).

MEDINA, C.L.; MACHADO, E.C.; SOUZA R.P. et al. Seasonal responses of photosynthesis and chlorophyll fluorescence of citrus seedlings grown in greenhouse with reflective shade net. In: INTERNATIONAL CONGRESS OF CITRUS NURSERYMEN, 6., Ribeirão Preto, 2001. Program \& abstracts. Ribeirão Preto, 2001. p.71.

MEDINA, C.L.; SOUZA R.P.; MACHADO, E.C et al. Photosynthetic response of citrus grown under reflective aluminized polypropylene shading nets. Scientia Horticulturae, v.96, p.115-125, 2002.

MELO, B. de. Estudos sobre produção de mudas de cafeeiro em tubetes. Lavras, 1999. 119p. Tese (Doutorado) - Universidade Federal de Lavras.

MORAES, F.R.P. de; GONÇALVES, J.C.; FRANCO, C.M. Renovação cafeeira. São Paulo: IBC; GERCA, 1970. 36p.

PAIVA, L.C. Produção de mudas de cafeeiro (Coffea arábica L.) em diferentes níveis de sombreamento e seus reflexos na implantação. Lavras, 2001. 61p. Dissertação (Mestrado) - Universidade Federal de Lavras.

PEREIRA, A.R.; ANGELOCCI, L.R.; SENTELHAS, P.C. Agrometeorologia: fundamentos e aplicações práticas. Guaíba: Livraria e Editora Agropecuária, 2002. 478p.

POLYSACK PLASTIC INDUSTRIES. Aluminet ${ }^{\circledR}$ : pantalla termo-reflectora; el tiempo nos dio la razón. Nir Yitzhak, s.d.(a) 1v. 
POLYSACK PLASTIC INDUSTRIES. Aluminet ${ }^{\circledR}$ : pantalla termo-reflectora; el triunfo de la investigación. Nir Yitzhak, s.d.(b) 1v.

RENA, A.B.; MAESTRI, M. Fisiologia do cafeeiro. In: RENA, A. B.; MALAVOLTA, E.; ROCHA, M. et al. Cultura do cafeeiro: fatores que afetam a produtividade. Piracicaba: Potafós, 1987. cap.2, p.13-66.

SILVA, A.M.; MIGUEL, A.; ROSA, R. Thermal radiation inside a single span greenhouse with a thermal screen. Journal of Agricultural Engineering Research, v.49, p.285-298, 1991.

SILVEIRA, A.J. da; MAESTRI, M. Crescimento de mudas de café (Coffea arabica L. cv. 'Bourbon') sob quatro níveis de luz, em Viçosa, Minas Gerais. Revista Ceres, v.20, n.111, p.354-369, 1973.

THOMAZIELLO, R.A.; OLIVEIRA, E.G. de; TOLEDO FILHO, J.A. de et al. Cultura do café Campinas: CATI; Fundação Cargill, 1996. 69p. (Boletim Técnico, 193).

VALERA, D.; MOLINA, F.; GIL, J. Las mallas como técnica de control climático en invernaderos. Vida Rural, n.139, p.50-52, 2001. 